\title{
RESEARCH
}

Open Access

\section{Gap models across micro- to mega-scales of time and space: examples of Tansley's ecosystem concept}

H. H. Shugart ${ }^{1 *}$, Adrianna Foster ${ }^{2}$, Bin Wang ${ }^{3}$, Dan Druckenbrod ${ }^{4}$, Jianyong Ma ${ }^{5}$, Manuel Lerdau', Sassan Saatchi ${ }^{6}$, Xi Yang ${ }^{1}$ and Xiaodong Yan $^{7}$

\begin{abstract}
Background: Gap models are individual-based models for forests. They simulate dynamic multispecies assemblages over multiple tree-generations and predict forest responses to altered environmental conditions. Their development emphases designation of the significant biological and ecological processes at appropriate time/space scales. Conceptually, they are with consistent with A.G. Tansley's original definition of "the ecosystem".

Results: An example microscale application inspects feedbacks among terrestrial vegetation change, air-quality changes from the vegetation's release of volatile organic compounds (VOC), and climate change effects on ecosystem production of VOC's. Gap models can allocate canopy photosynthate to the individual trees whose leaves form the vertical leaf-area profiles. VOC release depends strongly on leaf physiology by species of these trees. Leaf-level VOC emissions increase with climate-warming. Species composition change lowers the abundance of VOC-emitting taxa. In interactions among ecosystem functions and biosphere/atmosphere exchanges, community composition responses can outweigh physiological responses. This contradicts previous studies that emphasize the warming-induced impacts on leaf function.

As a mesoscale example, the changes in climate (warming) on forests including pest-insect dynamics demonstrates changes on the both the tree and the insect populations. This is but one of many cases that involve using a gap model to simulate changes in spatial units typical of sampling plots and scaling these to landscape and regional levels. As this is the typical application scale for gap models, other examples are identified. The insect/climatechange can be scaled to regional consequences by simulating survey plots across a continental or subcontinental zone. Forest inventories at these scales are often conducted using independent survey plots distributed across a region. Model construction that mimics this sample design avoids the difficulties in modelling spatial interactions, but we also discuss simulation at these scales with contagion effects.

Conclusions: At the global-scale, successful simulations to date have used functional types of plants, rather than tree species. In a final application, the fine-scale predictions of a gap model are compared with data from micrometeorological eddy-covariance towers and then scaled-up to produce maps of global patterns of evapotranspiration, net primary production, gross primary production and respiration. New active-remote-sensing instruments provide opportunities to test these global predictions.
\end{abstract}

Keywords: Pollution, Climate change, Global forest productivity, Individual-based models, Ecological scale, Forest dynamics

\footnotetext{
*Correspondence: hhs@virginia.edu

'University of Virginia, 291 McCormick Rd, Charlottesville, VA 22904, USA

Full list of author information is available at the end of the article
}

\section{Springer Open}

( ) The Author(s). 2020 Open Access This article is licensed under a Creative Commons Attribution 4.0 International License, which permits use, sharing, adaptation, distribution and reproduction in any medium or format, as long as you give appropriate credit to the original author(s) and the source, provide a link to the Creative Commons licence, and indicate if changes were made. The images or other third party material in this article are included in the article's Creative Commons licence, unless indicated otherwise in a credit line to the material. If material is not included in the article's Creative Commons licence and your intended use is not permitted by statutory regulation or exceeds the permitted use, you will need to obtain permission directly from the copyright holder. To view a copy of this licence, visit http://creativecommons.org/licenses/by/4.0/. 


\section{Introduction and background}

In this paper, we will provide examples of different models, all of which have are unified in their use of modeling forest dynamics, but operate over different time and space domains. These models simulate the physical structure of forests across their respective domains. Over the time of development of these models, there has been a parallel development of a remote-sensing capability to observe change are associated at the micro-, meso-, macroand mega-scales shown in Fig. 1. In this paper, we present examples of individual-based forest models, notably "gap models" to utilize these new data, to test models and to generate forest-ecosystem predictions and theories.

New technologies in remote sensing (RS) are providing rich challenges and opportunities to increase the understanding of forest ecosystems. These technologies can provide new observations of structural and functional traits to examine patterns and processes of ecosystems at different spatial and dimensional resolutions. The consequences of the interactions between pattern and processes, which is the yang and yin of terrestrial ecology, are at a relatively advanced level in forest ecosystem science, but there is still much more to learn, and results from research employing these new technologies can speed the learning processes. When Tansley originally coined the neologism, "ecosystem" in 1935, he made the point of that, "These ecosystems, as we may call them, are of the most various kinds and sizes." (Tansley 1935, page 299). Diagrams of scale using panels with time-and-space scales as axes of (1) disturbances or drivers of ecosystem change at particular time-and-space scales, (2) processes that respond to these drivers at equivalent scales and (3) patterns in ecosystems that arise at these scales (e.g. Delcourt et al. 1983; Druckenbrod et al. 2019) represent the "kinds-and-sizes" part of Tansley's definition. The union of drivers, processes, and patterns of responses define an ecosystem sensu Tansley - an ecosystem is a system as defined by its inputs, processes and outputs, all at commensurate space- and time-scales.

For example, consider a forested watershed in a given location as an ecosystem. Define precipitation, humidity and temperature as the inputs, transport and evapotranspiration as processes, and the variation in streamflow as the pattern. A second ecosystem might be a patch of forest inside the watershed where inputs of photosynthetically active radiation (PAR) drive photosynthesis to produce daily productivity patterns. While different from one another, both of these example forest ecosystems could be collocated and observed simultaneously. Sampling to characterize these two forest ecosystems would involve measuring different variables resolved across different time- and space-scales. Often, but not always, response times of the processes included in ecosystem formulations decrease with increasing with spatial scale (Druckenbrod et al. 2019).

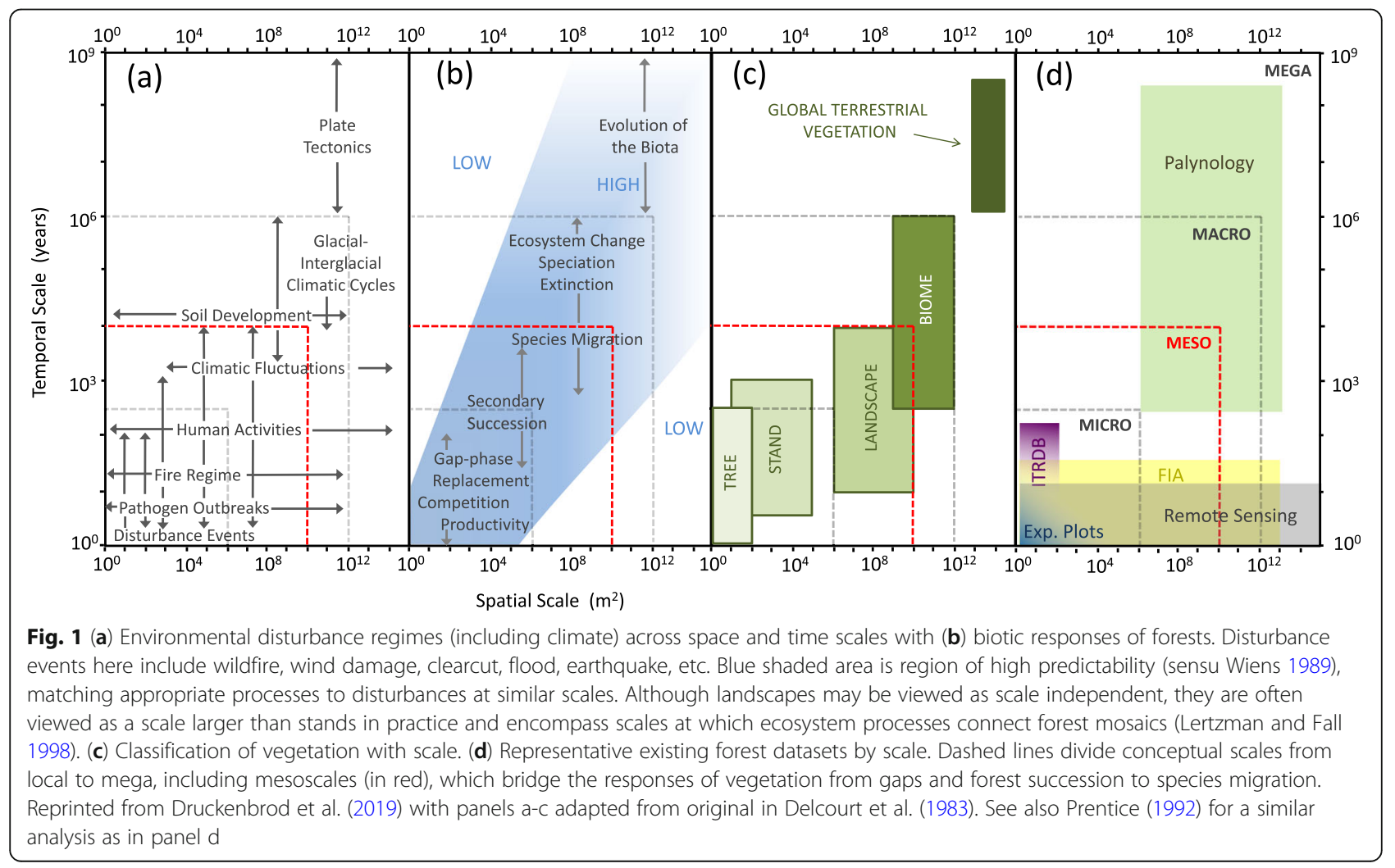


The multiple-scale aspect of Tansley's ecosystem implies a matching of the space-and-time domains of ecosystem drivers, processes and responses in spatial pattern (Wiens 1989), as in the examples just mentioned. Druckenbrod et al. (2019) recent review of these ecosystem concepts adds a fourth panel representing the time- and spacescales of available data sets (Fig. 1, also see Prentice 1992). Air- and satellite-borne remote-sensing represent different time-space domains from other data collections. These data often are collected across vast spatial scales with approximately daily-to-weekly sample-return intervals. The cumulative period of data collection for these instruments is at multiple decades in some cases (Fig. 1).

These remote-sensing (RS)-based data sets are an upscaled representation of processes normally studied at relatively small areas but not observed over areas (global-, regional- and landscape-scales) at a resolution for which there is no experimental comparison. Success in upscaling in these cases is difficult to test using traditional statistical procedures. Hence, correlation-related procedures, various pattern recognition techniques and, notably, ecosystem models arise as tools for the analysis of these data. Examples of earlier large-scale RS observations in addressing ecological questions of processes are determining how much PAR was being absorbed by a pixel on the terrestrial surface (Tucker 1979; Tucker et al. 2005), the extent of regional wildfires (Justice et al. 1996) and how climate change might be altering the global phenology of vegetation (Nemani et al. 2003). Shugart et al. (2015) saw the fusion of ecological modeling and remote sensing as a necessary synthesis needed to improve our modeling prediction of the ecological responses to global change for forests over regional and continental scales. Because the planet is warming (IPCC 2014), the need for such a capability could not be greater.

The United States National Aeronautics and Space Administration (NASA), the European Space Agency (ESA), and other national space agencies have developed and are beginning to launch a diverse array of new RS instruments. Many of these have already been tested from ground and airborne platforms. They are capable of distinguishing the vertical, horizontal, and 3-D structure of forests with either LiDAR (Light Detecting and Ranging) instruments (Lefsky et al. 2002), or RaDAR (Radio Detecting and Ranging) instruments (Shugart et al. 2010; Hall et al. 2011; Le Toan et al. 2011). Hyperspectral imaging spectroscopy can quantify leaf-and-species-level chemical and functional traits (Asner et al. 2012). At global and ecosystem scales, SIF (Solar-Induced Chlorophyll Florescence) has been demonstrated to be linearly correlated with GPP at the seasonal scale, and thus can potentially serve as an optical proxy for GPP (Frankenberg et al. 2011; Joiner et al. 2014; Yang et al. 2015; Coppo et al. 2017). A wide range of microwave and optical sensors are currently providing global observations of soil and canopy moisture, exchanges of water through evapotranspiration, capturing impacts of droughts on ecosystem function, tree mortality and carbon cycling (Saatchi et al. 2013; Zhou et al. 2014; Eswar et al. 2018; Fan et al. 2019).

The relationship between the RS observations and ecosystem models is also undergoing a paradigm shift. The different national aerospace agencies are currently in a major research phase of calibration and validation of the new instruments, which should provide a continuing string of independent tests for a priori forest model predictions, often made over large areas (Shugart et al. 2018). Many of these involve quantification of the physical structure of forests along with other attributes more usually measured at microscales (Fig. 1).

\section{Methods}

Our intent is to identify recent developments in forest gap models and to identify a fortuitous synergism with the capabilities of developing remote sensing technologies to evaluate these models. Since we are using models to compare change prediction at different scales, we divide the results section that follows to each of the ranges of time and space scales that we study. Forest gap models are a class of individual-based forest models (IBMs) that simulate the establishment, growth, and mortality of individual trees on independent plots, or forest patches, i.e. 'gaps', about the area of influence of a dominant canopy tree (Shugart 1984; Shugart et al. 2018). They are usually applied to forest of mixed tree sizes and species (more "natural" forests). The first of these models, JABOWA (Botkin et al. 1972) and FORET (Shugart and West 1977), were developed for use in the eastern United States. Follow-ons from these models are numerous and have been developed for use in the forests of China and Russia (Yan and Shugart 2005; Shuman et al. 2017), the western US (Bugmann 2001; Foster et al. 2017), the tropics (Huth and Ditzer 2000; Fischer et al. 2016), Europe (Bugmann and Solomon 2000), and boreal North America (Bonan 1989; Foster et al. 2019). Gap models simulate vegetation-soil interactions (Pastor and Post 1985; Bonan 1989; Foster et al. 2019), wildfire, windthrow and insect outbreak impacts on vegetation (Schumacher et al. 2006; Shuman et al. 2017; Foster et al. 2018), and volatile organic carbon (VOC) emissions from forests (Wang et al. 2017a).

Gap models compute individual tree growth, mortality, and regeneration through a combination of deterministic processes such as species-specific optimaldiameter-increment growth over time and individualtree growth response to environmental conditions, and stochastic processes such as stress-related mortality, regeneration success, and disturbances. Each simulated plot represents a single, independent forest gap undergoing successional and gap-dynamics processes 
through time. At a single location or "site", several hundred of such plots are generally run with similar starting conditions and site-wide parameters. Through the combination of deterministic and stochastic processes, individual plots differ from differences in mortality and regeneration events. Thus, output from a single simulated plot represents a potential outcome arising from the incorporation of these processes and interactions. Simulations typically are produced as Monte Carlo simulations. The average of an array of simulated plots represents the mean expectation of the characteristics of a forested landscape of indeterminate size, with the plots representing a dynamic mosaic of forest gaps, each with its own dynamical history in any given year (Shugart and Seagle 1985). The landscape-scale output from a gap model is similar to a random sampling of an actual landscape using forest inventory plots. Monte Carlo simulations on average produce properties of forest landscapes emerging over time as forest succession, cyclical dynamics, and forest response to shifting climate and disturbance regimes (Shugart and Woodward 2011; Foster et al. 2015; Shuman et al. 2015; Shugart et al. 2018).

Typically, individual-tree growth is simulated annually. Other processes such as soil moisture and decomposition dynamics are simulated at monthly- or dailytime scales. Individual trees differ in their tolerance to the ongoing environmental conditions on each plot based on their size, species, and current growth rate (Shugart 1984). Trees shade one another and compete for resources, and impact the soil conditions on the plot through changes in litter inputs and nutrient requirements (Pastor and Post 1985; Yan and Shugart 2005). Trees may die from prolonged low growth or by disturbances. Generally, disturbances such as fire or windthrow occur at the plot-level and do not spread to other plots within the same site. Regeneration of new trees is dependent on species-specific seed- and seedling banks, modified according to each species' abundance on the plot, regeneration strategy, and environmental tolerances (Yan and Shugart 2005).

Through explicit simulation of individual trees interacting with one another and their environment, gap models reproduce forest dynamics, compositional change, biomass, and structure at a resolution comparable to forest inventory data across a wide range of ecosystem types. Tabulations of dozens of examples, mostly used as model performance testing are in a sequence of reviews with progressive updates (Shugart 1984, 1998; Shugart et al. 1992; Shugart and Woodward 2011; Larocque et al. 2016). Through simulation at sites spanning large regions or continents, gap models can provide large-scale estimates of forest characteristics and response to environmental change (Shuman et al. 2015, 2017).

\section{Results}

Micro-scale $\left(10 \mathrm{~m}^{2}\right.$ to $\left.10^{6} \mathrm{~m}^{2}\right)$ models and observations The scaling up of production and emissions of Volatile Organic Compounds (VOCs) from leaf to ecosystem level needs to confront a challenge of high interspecific variability in the emissions of these compounds. In contrast to the primary metabolic processes of photosynthesis and transpiration, which show shallow phylogenetic conservation, secondary metabolism of VOCs is relatively deeply conserved (Harley et al. 1999; Monson et al. 2013). In other words, while photosynthesis, respiration, and transpiration show variability across species within a system in the order of tens of percent, the variation in VOCs production capability across species in a plant community is often orders of magnitude (Lerdau and Slobodkin 2002). This contrast in heterogeneity between primary and secondary metabolisms is globally true across biomes; both emitter and non-emitters of VOCs co-exist in an ecosystem, and among the emitters the emission capacity varies significantly (Loreto and Fineschi 2014). For forests, from temperate forests in the eastern United States to tropical systems about one-third of tree species produce isoprene; even low diversity ecosystems, such as boreal forests, contain a mixture of emitting and non-emitting species (Lerdau 2007). This inter-specific heterogeneity in VOCs production intrinsically requires both species-level accounting and vertically explicit accounting for variation within forest canopy, as light, operating through both direct effects and indirect effects on leaf temperature, is a crucial factor influencing VOCs emissions. By contrast, considering a model complexity versus efficiency tradeoff, existing VOCs models primarily adopt the scheme of plant functional types that is extensively used in biosphere models (Sellers et al. 1986). Such models, notably MEGAN (Guenther et al. 1995, 2012), have undoubtedly made significant contributions to understanding spatialtemporal patterns and magnitudes of VOCs emissions. However, a representation with plant functional types circumvents ecological complexity (in terms of both functional and structural diversity) in ecosystems. Remaining huge uncertainties in magnitude of VOCs emissions and a lack of prognostic capability arguably suggest that they are far from robust and should be improved.

Current state-of-the-art gap models, e.g. UVAFME, are better positioned to tackle these problems of complexity (Wang et al. 2016, 2017a, 2018). In contrast to models based on plant-functional types, a gap modelbased VOCs emission simulator is explicit in considering inter-specific emission variation and variation associated with vertical light change within canopy and tree crown (Fig. 2). Given the established forest gap modelling framework of being functionally and structurally explicit, the development is not challenging, especially for forest ecosystems in the eastern US where species-specific 


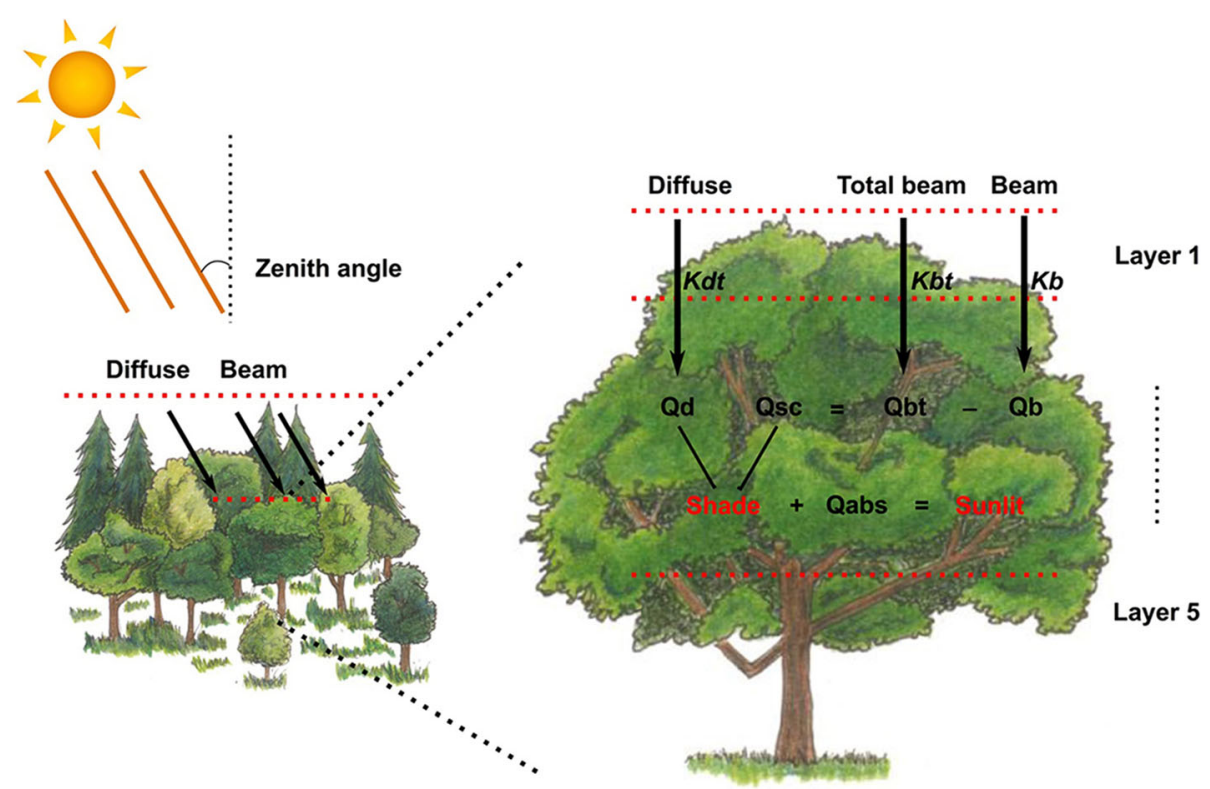

Fig. 2 Schematic of light transmission through forest canopy and tree crown in gap model-based forest VOCs emissions model-UVAFME-VOC. $K d t, K t$, and $K b$ represent the extinction coefficient for diffuse, total beam, and beam, respectively. Qsc and Qabs denote the scattered and absorbed beam radiation, respectively. Reproduced from Wang et al. (2017a)

VOCs emission factors are readily available (Fig. 3a and b). With this individual-based gap model, for the first time Tansley's ecosystem concept is enriched with a new dimension of secondary metabolism in terms of VOCs emissions. Thus, the interplay of ecosystem processes driven by primary and secondary metabolisms over time can be scaled and examined, facilitating a more complete elucidation of ecosystem dynamics and functioning.

The relative roles of environmental pressure versus forest community in driving ecosystem functioning in terms of both forest productivity and VOC emissions have been investigated (Fig. 3) with this new micro-scale gap model. These studies clearly indicate the considerable roles of community-level processes in mediating ecosystem responses to environmental pressures (Wang et al. 2016, 2018). For example, ozone, a secondary air pollutant that is harmful to both human health and plant activity, is assumed responsible for global-vegetationproductivity decline and land-carbon-sink reduction (Sitch et al. 2007; Wang et al. 2017b). However, longterm simulations suggest that, over time, ozone does not necessarily dampen forest productivity and carbon stock (Wang et al. 2016). This system-level result emerges from a community-level process of ozone-resistant species replacing sensitive ones (Fig. 3c). Moreover, we found that ozone pressure enhances isoprene emissions by favoring isoprene-emitting species which are less ozone sensitive (Fig. 3d), a result of a potential plant metabolic tradeoff of resource consumption versus stress tolerance. Besides ozone, increasing temperature is another pressing driver faced by forest ecosystems. Contrary to the prevailing opinion of increasing VOCs emissions under climate warming, increasing temperature does not necessarily continuously enhance forest isoprene emissions because of forest compositional changes in relative abundance of emitters versus non-emitters (Fig. 3e). These results strongly support the role of forest community in mediating the forest ecosystem responses to global change agents, pointing to the deficiency of PFT-based models in scaling up physiology directly and to the advantage of forest gap model in incorporating community processes (Wang et al. 2016, 2018).

These initial micro-scale explorations and findings with a forest gap model regarding secondary metabolismmediated processes warrant more investigations into their performance at differing locations and into their larger scale implications for biosphere-atmosphere interactions (Lerdau 2007; Wang et al. 2019). Achieving such scale-ups of these local scale emissions to larger scales can be inspired by the following discussions on applications to addressing patterns of forest composition and structure at scales from meso- to macro-scale.

\section{Meso-scale $\left(10^{6} \mathrm{~m}^{2}\right.$ to $\left.10^{10} \mathrm{~m}^{2}\right)$ models and observations}

At the meso-scale, gap-models scale from dynamics at the individual plant- and stand-scale to those of whole landscapes. At the stand-scale, these models simulate exogenous and endogenous forest dynamics through explicit tracking of individuals throughout their life cycle, from initial regeneration following release by the death 

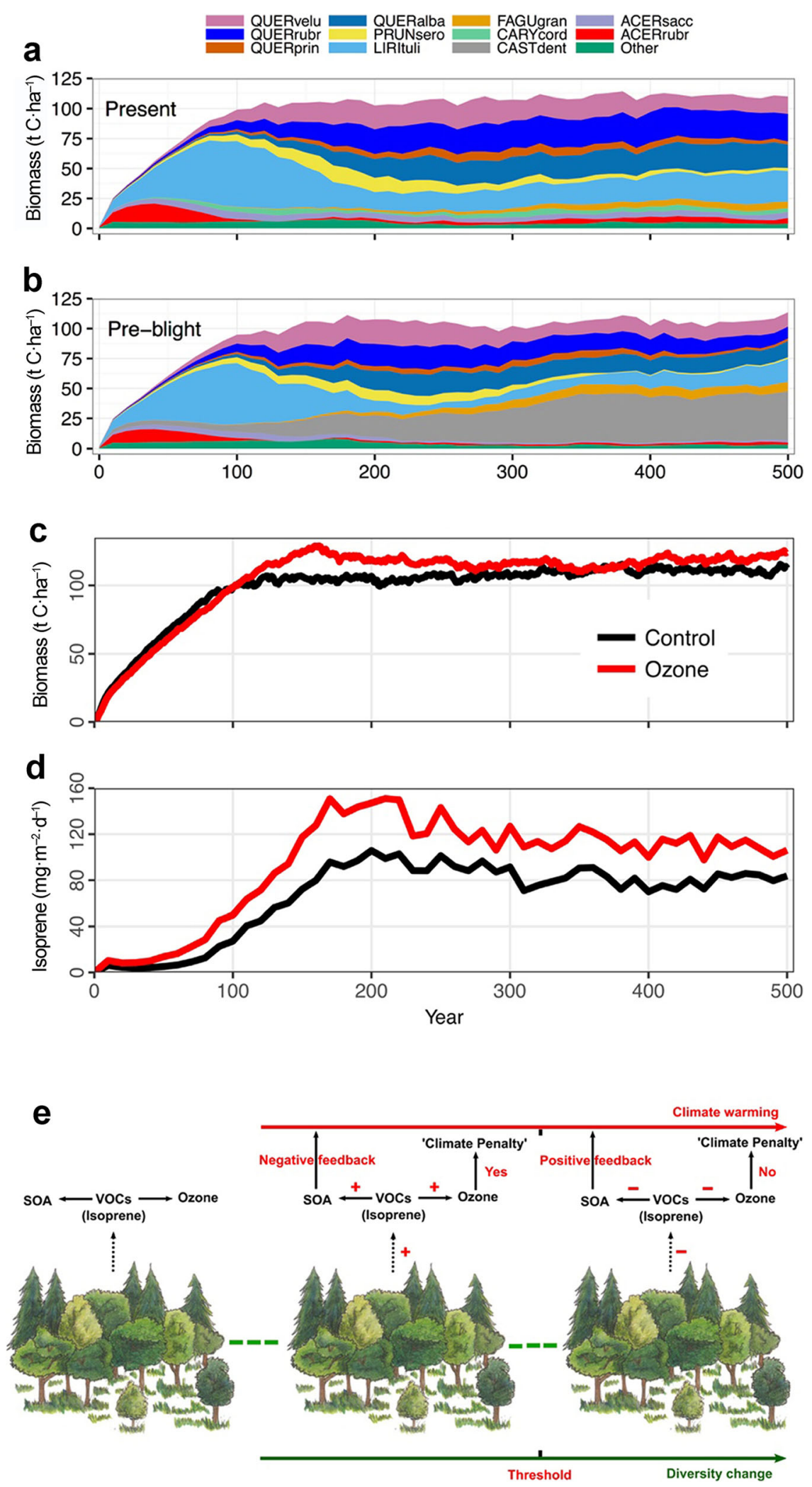

Fig. 3 (See legend on next page.) 
(See figure on previous page.)

Fig. 3 Micro-scale simulations of forest dynamics in composition, productivity, and hydrocarbon emissions in Southeastern US using UVAFMEVOC. (a) Contemporary forest dynamics in the Southeastern US. (b) Forests around the 1900s with American Chestnut (pre-blight). The width of each color band represents the biomass of different species (see the color code in Wang et al. 2017a). (c) Unsuppressed forest biomass and (d) enhanced hydrocarbon emissions driven by ozone pressure, which is implemented by imposing species-specific sensitivity on the forest illustrated in panel a. (e) Schematic of diversity-mediated threshold of forest hydrocarbon production under warming, where ecological suppression offsets physiological enhancement. Prior to and beyond the threshold, distinctive feedback mechanisms between climate and atmospheric chemistry mediated by forests may occur. Figures reproduced from Wang et al. (2016, 2017a, 2018)

of a canopy dominant, through their growth and response to local-scale weather, site, and environmental conditions, and to their mortality because of low growth or disturbances (Shugart et al. 2018). These individuals additionally interact with one another via shading and competition for other resources as well as through impacts on their abiotic environment (e.g. soil depth, soil moisture, litter quality, etc.). Gap models thus capture how individual trees and forest stands respond to and interact with their changing environment. They are particularly useful in forest ecosystems where the disturbance regime and successional dynamics within the region lead to a heterogeneous landscape of mixed-age, mixed-species stands. Individual trees respond differently to their environment and disturbance events based on their size, age, species, and life history. Gap models, which track all of these variables on an individual-scale, potentially can more closely match actual forest response to change over a wider domain. In particular, gap models can aid in simulating multi-scale interactions between vegetation, disturbances, and climate.

\section{An example landscape-scale gap model application}

Foster et al. (2018) utilized the individual-based gap model, UVAFME, to predict interactions between vegetation, bark beetle infestation, climate change, and other disturbances in the subalpine zone of the US Rocky Mountains. Spruce beetles (Dendroctonus rufipennis (Kirby)) are an aggressive bark beetle species that infests spruce (Picea spp.) species throughout the western United States, Alaska, and Canada (Jenkins et al. 2014). Because spruce beetles preferentially attack older and larger spruce trees, the post-outbreak species composition and stand structure tend to be a mix between small $(<10 \mathrm{~cm}$ diameter) spruce trees as well as variable-sized non-host tree species (Veblen et al. 1991). This post-outbreak composition and structure is in contrast to the effects of standreplacing fire in the western US, whereby even-aged, often even-species stands tend to arise.

Spruce beetles infest trees through "mass attacks", whereby pheromones released by attacking beetles draw more and more beetles to a host tree. This strategy allows for successful infestations of otherwise healthy trees (Raffa et al. 2008). The success of a mass-attack is therefore predicated on the size, age, and condition of the host tree, as well as the local population size of beetles. Beetle population size is additionally impacted by the availability of suitable hosts and climate impacts on survivorship and population growth rate (Berg et al. 2006; Hansen et al. 2011, 2016; Hart et al. 2015). Through explicit simulation of individual trees and individual stands, UVAFME captured the multi-scale factors that influenced infestation rate under current and future climate scenarios (Foster et al. 2018). The infestation probability of a spruce tree was determined by the tree-level characteristics such as size, stress-level, and proximity to other infested trees, standlevel characteristics such as basal area of spruce and down woody debris, and site-wide climate characteristics. With this methodology, the model accurately produced the shifts in species composition and stand structure following an outbreak seen in field studies documenting such events (Veblen et al. 1991; Derderian et al. 2016). This ability was in large part due to the fine-scale nature of UVAFME. Without the representation of vegetation dynamics at their inherent scale - individual trees - the detailed response of forest stands to outbreaks cannot be simulated without strong assumptions about stand structure.

Through a Monte Carlo-style aggregation of several hundred plots, UVAFME additionally represented landscape-level forest properties and dynamics over time in response to spruce beetle outbreaks. At this scale the model produced, without prescription, emergent properties of these interactions, predicting the rising and falling of infestation rates over time (Foster et al. 2018) (Fig. 4). This periodicity is comparable to periodicities in spruce beetle outbreaks found in field studies (Veblen et al. 1994; Zhang et al. 1999; Berg et al. 2006; Hart et al. 2014), and arises as a result of the nature of the vegetation-spruce beetle system. During an outbreak, most if not all of the larger spruce trees are killed, leaving only trees too small to sustain high levels of beetle populations (DeRose and Long 2012). Beetle populations then decline, allowing the surviving trees to grow and eventually become suitable for infestation. Some outbreak-inciting event (e.g. drought, windthrow, etc.) then occurs and starts the cycle anew (O'Connor et al. 2015). This emergent property of treeand stand-level infestations was not prescribed within UVAFME, yet the model was able to produce it via simulation of hundreds of plots as a mosaic of forest stands across a landscape, each undergoing separate fine-scale 

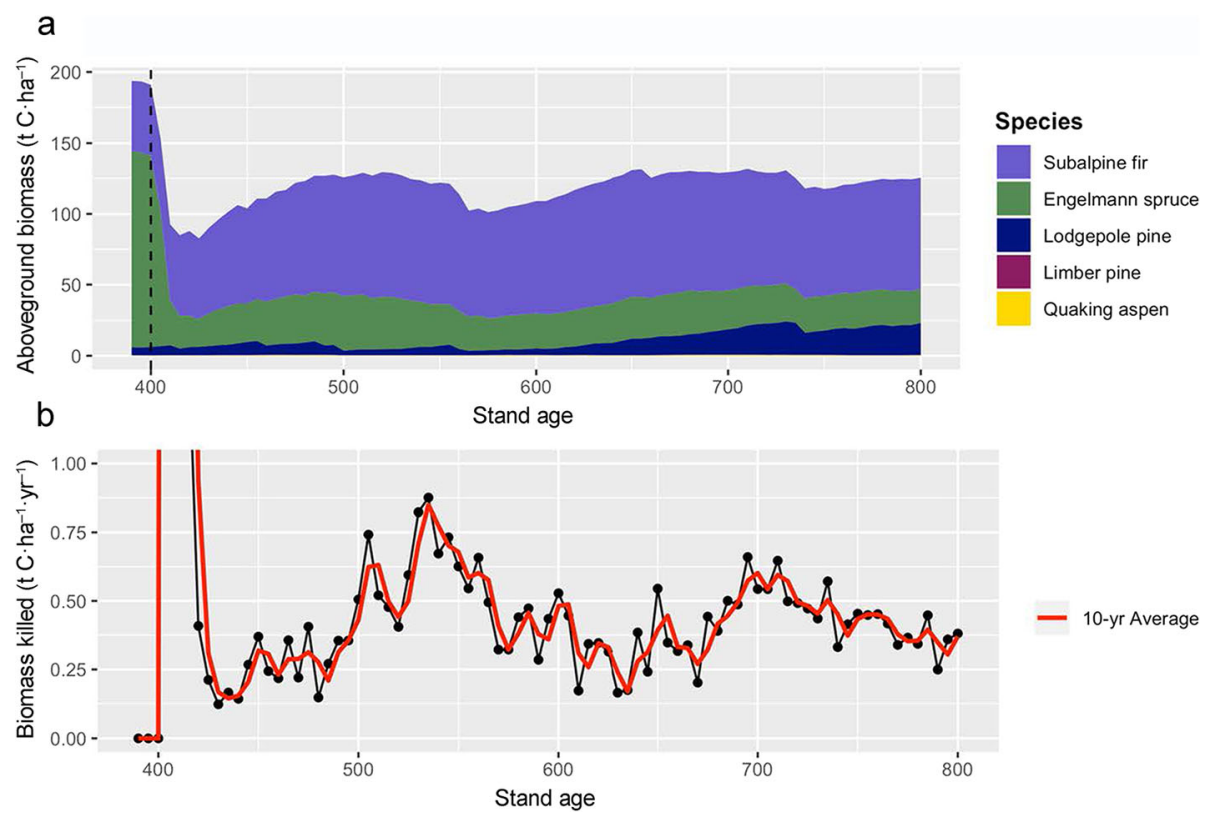

Fig. 4 (a) UVAFME-simulated species-specific biomass (t C.ha ${ }^{-1}$ ) at the USDA Forest Service's Glacier Lakes Ecosystem Site site in southern Wyoming. Spruce beetle infestations of Engelmann spruce (Picea engelmannii) begin at simulation year 400. Cyclical dynamics can be seen over time in the spruce biomass as a result of cycles of infestation-related mortality. (b) Spruce-beetle killed Engelmann spruce biomass (t C.ha ${ }^{-1} \cdot \mathrm{yr}^{-1}$ ) over time for the same simulation averaged across all 200 plots. The red line corresponds to a 10-year running average. Redrawn from Foster et al. (2018)

vegetation-disturbance dynamics but experiencing similar climate conditions.

This type of multi-scale modeling is crucial for capturing vegetation drivers and biotic-abiotic interactions under current and future climate scenarios. In ecosystems where such feedbacks are tied to species- and treesize specific responses to disturbances, gap models can simulate the potential non-linear and cascading effects of shifting climate and disturbance regimes (Shugart and Woodward 2011; Seidl et al. 2017). Simulations at the stand $\left(500 \mathrm{~m}^{2}\right)$ and landscape scale $\left(10^{6} \mathrm{~m}^{2}\right)$ can then be applied across whole regions or continents to simulate forest change across very large scales (Shuman et al. 2017; Foster et al. 2019).

\section{Scaling-up to regional applications}

A recent application with UVAFME in boreal Alaska found that simulating the tight linkage at the tree- and stand-level between vegetation demography, soil characteristics, wildfire, and climate was necessary to represent forest dynamics, structure, and composition across the entire region (Foster et al. 2019). Vegetation interactions along with soil characteristics and the fire regime dominate the Alaskan boreal zone (Viereck et al. 1983; Chapin III et al. 2006b; Johnstone et al. 2010a). In these forests, different stable states of vegetation type arise because of species-specific vegetation-soil-fire interactions. Black spruce (Picea mariana) is able to grow and reproduce on deep, poor nutrient quality, moist soils with shallow permafrost layers (Viereck et al. 1983; Burns and Honkala 1990). The slow decay rate of black spruce litter (Flanagan and Van Cleve 1983; Vance and Chapin III 2001) leads to the buildup of a thick organicmoss layer, a shallow active layer, low nutrient contents in the soil, and the dominance of black spruce over other tree species that do not tolerate such conditions. In contrast, mixed white spruce (Picea glauca) and deciduous stands generally occur on warmer slopes without permafrost. These tree species are less tolerant of deep soils, permafrost, and low nutrients, and the faster decay rate of deciduous litter allows for these species' more favorable conditions to persist (Johnstone et al. 2010a). Such self-perpetuating ecotypes additionally interact with the fire regime, as black spruce stands are more flammable than deciduous stands, and black spruce depends on fire for rapid post-fire reproduction via serotinous cones (Greene and Johnson 1999).

Foster et al. (2019) updated UVAFME to include daily freeze/thaw and seasonal active layer depth dynamics, which in turn impacted soil moisture dynamics, litter decay, and individual tree growth and reproduction. Litter decayed according to site/soil conditions as well as litter characteristics, which differed based on litter type (e.g. leaves, branches, boles, etc.) and genus (for leaves). Thus, the litter decay rate and litter influx were tied to the species composition, forest structure, and 
successional cycle of each simulated plot. The decay rate and litter influx in turn impacted the depth and nutrient content of the humus and litter layers, which fed back to soil moisture and permafrost dynamics as well as tree growth and regeneration (Foster et al. 2019). The updated model additionally tied fire intensity to litter content and characteristics, with thicker, drier soils burning at higher intensities. Fire intensity along with forest structure and species composition impacted fire mortality and post-fire regrowth on each stand (Shuman et al. 2017; Foster et al. 2019).

With these updates to UVAFME each individual tree's growth, mortality, and decay influenced not only the surrounding trees on the plot but also the environmental conditions that those trees experience. Prior to these updates, the model could not accurately reproduce forest characteristics and dynamics within the study region (Foster et al. 2019). Even intermediate testing between model updates (e.g. following permafrost/soil moisture updates but before decomposition updates) did not produce accurate results when compared to inventory data or expected forest successional dynamics. It was only until all biotic-abiotic feedbacks were included in UVAFME that the model could simulate the forest successional dynamics and resulting interactions. Such a failure to simulate forest dynamics accurately within boreal Alaska without the tree-level links between vegetation, soils, wildfire, and climate is unsurprising, given the importance of these interactions in structuring the mosaic of forest types and ages within the region (Chapin III et al. 2006a, 2006b; Johnstone et al. 2010a).

The fine-scale interactions between trees and their environment in this study scaled up to influence regionwide changes in biomass, structure, and composition. Foster et al. (2019) found that species- and tree sizespecific interactions drove changes in vegetation and soil conditions under warming temperatures (Fig. 5). Over the course of the climate change simulation, the most important growth stressors shifted from mainly low temperature and shade stress to drought and nutrient stress. Additionally, at the stand-scale, changes in vegetation in response to climate impacted the soil and fire

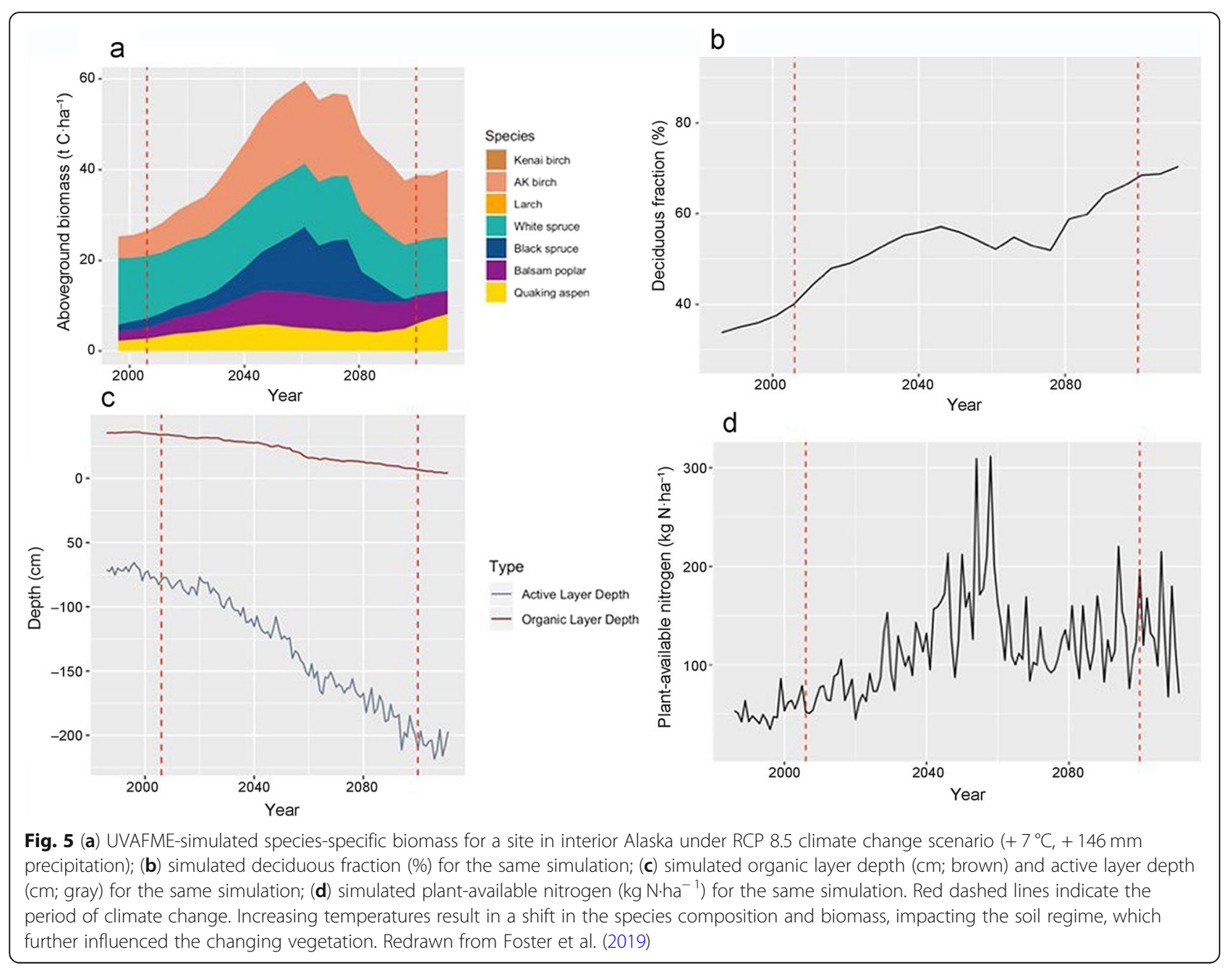


regime - with historically cold, black spruce stands underlain by permafrost shifting to dry deciduous stands with thin soils and a deep active layer. These results indicate that along with drought stress, tree-tree competition for resources and vegetation-soil feedbacks will become increasingly important drivers of vegetation change. When applied across the Tanana River Basin $\left(\sim 115,000 \mathrm{~km}^{2}\right)$, UVAFME was also able to predict the differential response of forests across the region to climate change depending on site characteristics and pre-climate change species composition and soil conditions.

Other ecosystem models investigating these bioticabiotic interactions have been applied within the North American boreal region (Euskirchen et al. 2009; Johnstone et al. 2011; Genet et al. 2013; Fisher et al. 2014; Trugman et al. 2016; Mekonnen et al. 2019). However, most of these applications have represented vegetation at much broader scales in term of composition (groups of plant functional types rather than species) and structure ("big-leaf" canopies rather than individual trees), or have used a state-transition modeling system rather than a process-based simulation of forest dynamics. Given the importance of fine-scale interactions within the boreal region, as well as other forest ecosystem types (Keane et al. 2001; Chapin III et al. 2006a; Araujo and Luoto 2007; Purves and Pacala 2008; Shugart et al. 2018), this lack of fine-scale vegetation representation has implications for predicting both the current and future state of forests, worldwide.

Without representation of individual species and their response and interaction with their environment, much of the detail and potential for non-linear, interacting effects is lost. Fisher et al. (2014) compared simulations of annual carbon flux over Alaska across 40 broad-scale terrestrial biosphere models and found high variability (both in magnitude and in direction) across the model simulations, citing uncertainty in NPP, plant-functional type, and soil conditions as some of the more important factors driving this overall uncertainty (Fisher et al. 2018). Many of these broad-scale models represent boreal vegetation grouped into needle-leaved evergreen (including both black and white spruce), needle-leaved deciduous (larch), and broadleaved deciduous functional types (Fisher et al. 2018; Mekonnen et al. 2019). The grouping of black and white spruce is problematic given the species' differential tolerances and resource requirements (Burns and Honkala 1990; Chapin III et al. 2006a), as well as their differential impacts on local-scale soil conditions and the fire regime (Johnstone et al. 2010a). Under climate change scenarios, the compounding and non-linear vegetation, soils, and wildfire responses may alter the existing biotic-abiotic feedbacks (Johnstone et al. 2010b), resulting in new species mixtures and interactions which can only be predicted if species-specific effects are considered at a fine scale.
The representation of fine-scale forest structure is important for considering tree competition, biophysical impacts on climate, as well as how trees of different sizes respond to disturbances and their environment. Treetree competition is important for determining forest response to climate change (Purves and Pacala 2008) and implies the use of individual-based models. Tree size impacts disturbance mortality, response to environmental stressors, and the local-scale environment that a tree experiences throughout its life (Shugart 1998; Keane et al. 2001; McDowell and Allen 2015; Hood et al. 2018) (Fig. 4). Models that do not include simulation of a mixedage, mixed-size forest lose this detail and under scenarios of climate change may not be able to fully capture how forests will respond and interact with their changing environment.

\section{Macro-scale $\left(10^{10} \mathrm{~m}^{2}\right.$ to $\left.10^{12} \mathrm{~m}^{2}\right)$ and mega-scale $\left(>10^{12} \mathrm{~m}^{2}\right)$ models and observations}

Many of the applications of gap models, have simulated landscape-scale units. Even the earliest gap models included site variables (soil depth, water capacity of the soil, site quality, etc.) that could vary over the simulated landscape. As was mentioned in the section above, the most straightforward simulations of landscapes are to exercise the model to predict the fates of survey plots the size of a simulated gap-model plot with these "plots" at a spacing that reduces contagion effects to a minimum. These contagion effects can be important and several extensions of gap models have simulated and tested against the effects of contagion. One approach to this problem was manifested as the ZELIG code, in which a gap-model is used as a computational "window" to change each tree in a dynamically changing gridded map (Urban et al. 1991). Windowing is used in other individual-based models in other fields. For example, the simulation of the development of galaxy geometry arising from billions of gravitational interacting stars is solved computing the effect of nearby stars on each single star. This effectively converts the computation of gravitational effect from a function of the square of the number of stars (when all stars interact with one another) to a function of number of stars.

\section{Macro-scale (regional-scale) applications}

Forest structure and composition at the meso- and macro-scale impact biophysical feedbacks to climate through changes in albedo, surface roughness, and latent heat flux (Bonan et al. 1992; Liu et al. 2006). Thus, changes in structure and composition have the capacity to impact the trajectory of climate regionally and even globally. Historically, gap models were excluded from use in global climate models due to limits in computer processing power (Shugart et al. 2018). Gap models have 
a rich and early history of simulating the dynamic changes in landscapes and regions during the Quaternary (Solomon et al. 1980, 1981; Solomon 1986). However, modern technology now allows these fine-scale models to be applied continentally (Sykes and Prentice 1996; Shuman et al. 2017) and provides the impetus for continental and global-scale applications that couple vegetation and climate.

Weishampel et al. (1992) included side-shading effects on canopy geometry in natural Douglas-fir (Pseudotsuga menziesii) of different ages. They tested their prediction against semivariance patterns in canopy heterogeneity that were independently collected using high-resolution photogrammetry. ZELIG has subsequently been used to predict expected forest patterns over time and spatial resolution (van Tongeren and Prentice 1986; Huston and Smith 1987; Smith and Urban 1988; Huston et al. 1988) and in several applications in Boreal forests (Larocque et al. 2006, 2011). Recent simulations for the Russian boreal forest with the SIBBORK model (Brazhnik and Shugart 2015) have simulated contagious effects including orographic shading - a south-facing slope in a deep valley is compositionally and structurally different from a south-facing slope without shading without the north-facing opposite valley side (Brazhnik and Shugart 2016). The SIBBORK model has also been applied to one of the principal contagion effects in boreal forests, wildfire (Brazhnik et al. 2017). Generally, the inclusion of spatial effects in individual-based models has been limited by data for parameter estimation and not by modeling limitations.

\section{Mega-scale (global-scale) applications}

Canopy process models simulate the flux of heat, $\mathrm{CO}_{2}$ and water between plant canopies and their environment over time scales of a few seconds to a day. They represent the canopy as a single- or multi-layer unit with a fixed structure (i.e. leaf area). Photosynthesis and transpiration are simulated by estimating microclimatic variation and stomatal conductance for the canopy (or canopy layers). The inside of a leaf and its external environment are coupled by the stomata, microscopic pores in the leaf surface that can change under different environmental conditions and are controlled by the plant. If these stomatal openings are relatively large, resistance to molecular diffusion is low $-\mathrm{H}_{2} \mathrm{O}$ diffuses out from the moist spaces inside the leaf and $\mathrm{CO}_{2}$ diffuses into the same internal spaces to compensate for the $\mathrm{CO}_{2}$ taken up by the plant through photosynthesis. As the stomatal aperture closes, the resistance to these diffusion-based transfers increases. Thus, the balance of $\mathrm{CO}_{2}$ and $\mathrm{H}_{2} \mathrm{O}$ are interwoven. Because the loss of water from the leaf is evaporative, the outward flux of water also removes heat from the leaf. In canopy process models, formulae relating the $\mathrm{CO}_{2}, \mathrm{H}_{2} \mathrm{O}$ and energy fluxes for leaves form bases for simulating the $\mathrm{CO}_{2}, \mathrm{H}_{2} \mathrm{O}$ and energy fluxes of plant canopies over large areas.

For example, Woodward (1987) developed a simple model of the energy and hydrological balance of a plant canopy using the Penman-Monteith equation (Penman 1948; Monteith 1981) to determine canopy transpiration. The water transpired by plant canopy of a given leaf area, along with evaporated water, is subtracted from the water held in the soil. If over the course of a year the soil dries too much or the soil is unable to recharge its water, then the leaf area is assumed too high and a lower value for leaf area used until the maximum sustainable leaf area is found. Provided with spatial data for the environmental conditions needed by the model (solar radiation, precipitation, temperature, etc.), the model simulates the expected leaf area at regional and global scales.

Woodward's model illustrates several of the general features found in homogeneous landscape models:

- "An Appeal to Optimality" as seen in the procedure used to determine the expected leaf area at a location - that the vegetation will optimize its leaf area to use the available water in a region. This optimum balances the positive tendency for vegetation to add leaf area when water is available with the constraint that, if vegetation "mines" the soil water beyond the resupply rate, then plant death and leaf shedding will reduce leaf area. More recently, it has become apparent that this approach to optimization incorrectly assumes that optimization at the vegetation-assemblage scale is evolutionarily stable; in fact, canopy optimization is only stable when it occurs at the individual tree scale, which leads to an assemblage-scale canopycover that is lower than possible when optimization occurs at assemblage-scale (Anten and Hirose 2001). Another constraint is that vegetation cannot gain additional net leaf area once the lowest layer of leaves is sufficiently shaded.

- "Use of Limiting Factors," particularly for light and water as in Woodward example. The heat balance of the vegetation links to the water evaporated from the vegetation by the Penman-Monteith equation.

- "An Expectation of Generality" allowing the models to be applied to vegetation worldwide. This is often based on physically-based heat-flux equations solved at equilibrium ("Equilibrium Seeking Behaviour").

Inasmuch as gap models have included metabolism (Friend et al. 1993), they have tended to focus on photosynthesis, respiration, and transpiration because of the central role these processes play in the mass and energy balance of an ecosystem. 
Simulation of global carbon fluxes from natural systems has traditionally involved models that scale up ecological processes from study sites to large, assumed homogeneous units of about $\sim 0.1^{\circ}$ to $\sim 0.5^{\circ}$ latitude $\times$ longitude blocks. Many of these aggregated models such as TEM (McGuire et al. 1992), CENTURY (Parton et al. 1993), CASA (Potter et al. 1993), IBIS (Foley, 1994), SiB2 (Sellers et al. 1996), LPJ (Sitch et al. 2003) and ORCHIDEE (Krinner et al. 2005) have been used to project ecosystem carbon fluxes. There are similar models that use stand-based dynamics or even individual-based models to include population dynamic processes such as plant establishment, mortality and resource competition, notably: Hybrid (Friend et al. 1997), LoTEC (King et al. 1997), LPJ-GUESS (Smith et al. 2008), TRIPLEX (Peng et al. 2002) and INTCARB (Song and Woodcock 2003).

A direct application of a gap model to simulate global forests is the use of the FORCCHN model to evaluate the global forest carbon fluxes ( $\mathrm{Ma}$ et al. 2017). The FORCCHN model has several significant aspects. It can produce daily estimates of gross primary production (GPP), ecosystem respiration (ER) and net ecosystem production (NEP), using canopy modeling approaches we discussed in the section on micro-scale models (above). This allows the physiological aspect of the model to be tested against 37 forest eddy-covariance sites, which were drawn from the daily data in the LaThuile FluxNet free use data set (http://www.fluxdata. org), AmeriFlux (http://ameriflux.ornl.gov), CarboEuroFlux (http://www.carboeurope.org), ChinaFlux (http:// www.chinaflux.org) and FFPRI FluxNet (http://www2. ffpri.affrc.go.jp/labs/flux/index.html). Figure 6 shows four examples using monthly data from four of these study sites against the FORCCHN model. Across all 37 sites, the daily correlation coefficients averaged 0.72 for GPP, 0.70 for ER and 0.53 for NEP.

After inspecting the ability of the FORCCHN model to reproduce GPP, NEP and ER for the 37 eddy correlation sites, the model was then applied to the problem of estimation of global carbon fluxes from forests. To do so one must develop a data set to drive the FORCCHN model:

1) The climatological forcing was from Princeton University over the 1982 2011 period at a grid

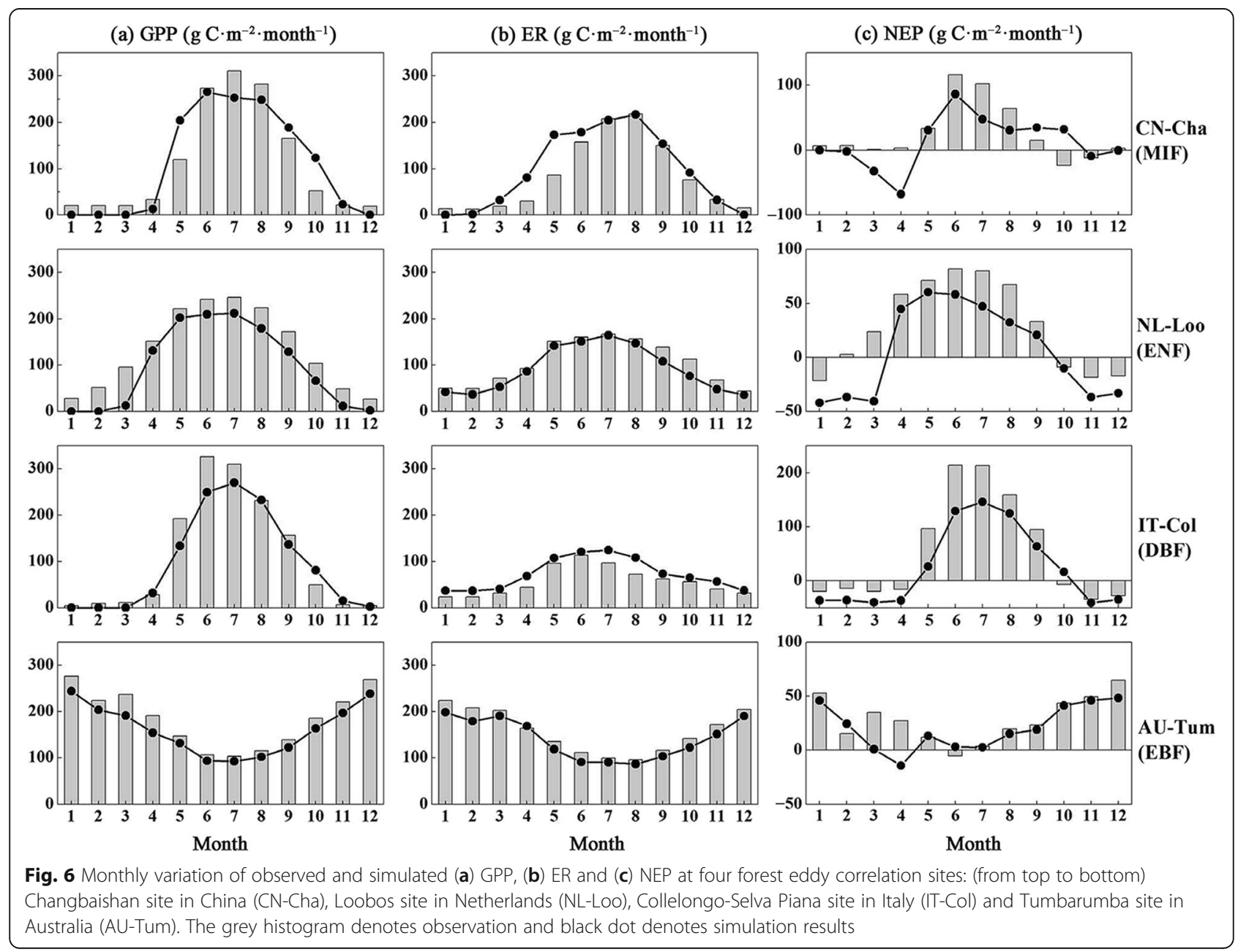


resolution of $0.5^{\circ} \times 0.5^{\circ}$ (http://hydrology.princeton. edu, Sheffield et al. 2006). Derived through a combination of reanalysis data and observations, these variables include the daily maximum and minimum air temperature $\left({ }^{\circ} \mathrm{C}\right)$, precipitation $(\mathrm{mm})$, relative humidity (\%), wind speed $\left(\mathrm{m} \cdot \mathrm{s}^{-1}\right)$, atmospheric pressure $(\mathrm{hPa})$ and total solar radiation $\left(\mathrm{W} \cdot \mathrm{m}^{-2}\right)$.

2) Soil parameters are soil organic matter (carbon and nitrogen pool in units of $\mathrm{kg} \mathrm{C} \cdot \mathrm{m}^{-2}$ and $\mathrm{kg} \mathrm{N} \cdot \mathrm{m}^{-2}$, respectively), soil physical parameters and litter pool decomposition parameters. The soil physical parameters are strongly dependent on the geographical position and include the soil field capacity $(\mathrm{mm})$, wilting point $(\mathrm{mm})$, bulk density $\left(\mathrm{kg} \cdot \mathrm{m}^{-3}\right)$, sand content (\%), silt content (\%) and clay content (\%). The Global Gridded Surfaces of Selected Soil Characteristics (Global Soil Data Task Group 2000) coupled with Harmonized World Soil Database (Nachtergaele et al. 2012) provide resources for the soil organic matter and physical parameters. The litter pool decomposition parameters are calculated according to Kirschbaum and Paul (2002). Moreover, to insure that the allocation proportion of organic carbon in ten soil pools are in equilibrium in FORCCHN, the model is run for 300 years at each grid point and then the new allocation proportions are used as model input data to simulate $\mathrm{C}$ fluxes for the past 30 years.

3) Global forest types, used to select which tree functional types are used, are derived from International Geosphere Biosphere Program-Data and Information Service (IGBP-DIS) DISCover land cover classification system, with a spatial resolution of $0.5^{\circ} \times 0.5^{\circ}$ (Loveland et al. 2009). The 8-day $5-\mathrm{km}$ LAI of Global LAnd Surface Satellite (GLASS) in 1982 (Liang et al. 2013) is also used to drive the model. Product developers ascribe quality control flags based on LAI to screen and reject poor quality data. The 8-day LAI are composited into the yearly maximum and minimum values. Note that satellitederived LAI datasets are resampled to the geographic projection and spatial resolution of the global climatological forcing.

The resultant global simulations for forest GPP and ER (Fig. 7) are consistent with Model Tree Ensemblebased GPP estimates (Jung et al. 2011) - except that FORCCHN-derived GPP is about $\sim 300 \mathrm{~g} \mathrm{C}^{-2} \cdot \mathrm{yr}^{-1}$ smaller in most tropical rain forest and $\sim 900 \mathrm{~g} \mathrm{C} \cdot \mathrm{m}^{-2} \cdot \mathrm{yr}^{-1}$ larger in parts of south-central Africa. Over the simulated interval (1982-2011) both GPP and ER significantly increased $(P<0.01$, see $\mathrm{Ma}$ et al. 2017) across all forest types. The forest type with the greatest $\mathrm{CO}_{2}$ uptake by photosynthesis and $\mathrm{CO}_{2}$ release by ecosystem respiration were evergreen broadleaf forests with multi-year averaged values for GPP of $2631 \pm 233 \mathrm{~g}$ $\mathrm{C} \cdot \mathrm{m}^{-2} \cdot \mathrm{yr}^{-1}$ (mean \pm 1 standard deviation) and ER of $2513 \pm 216 \mathrm{~g} \mathrm{C} \cdot \mathrm{m}^{-2} \cdot \mathrm{yr}^{-1}$. Deciduous broadleaf forest (GPP of $1428 \pm 183 \mathrm{~g} \mathrm{C} \cdot \mathrm{m}^{-2} \cdot \mathrm{yr}^{-1}$; ER of $1346 \pm 184 \mathrm{~g}$ $\mathrm{C} \cdot \mathrm{m}^{-2} \cdot \mathrm{yr}^{-1}$ ) and mixed forest (GPP of $961 \pm 84 \mathrm{~g}$ $\mathrm{C} \cdot \mathrm{m}^{-2} \cdot \mathrm{yr}^{-1}$; ER of $917 \pm 84 \mathrm{~g} \mathrm{C} \cdot \mathrm{m}^{-2} \cdot \mathrm{yr}^{-1}$ ) were the next two most important types of forests.

The role of forests as sources or sinks in global carbon budgets is a consequence of NEP. NEP is the difference between two relatively large numbers, GPP-ER. For global forest ecosystems FORCCHN gave an annual total GPP and ER of $58.83 \pm 5.61$ and $55.77 \pm 5.18 \mathrm{Pg} \mathrm{C} \cdot \mathrm{yr}^{-1}$ for global forest ecosystems during 1982-2011, such value is within the range reported by other GPP models. Global forest ecosystems as simulated by FORCCHN contribute a substantial $C$ sink for the same period, with total NEP being $3.06 \pm 0.67 \mathrm{Pg} \mathrm{C} \cdot \mathrm{yr}^{-1}$. This is also comparable to the results from studies using observationbase estimations of 52.61-67.54 Pg C.yr ${ }^{-1}$ (Beer et al. 2010) and from satellite-based observations of 37.59$59.77 \mathrm{Pg} \mathrm{C} \cdot \mathrm{yr}^{-1}$ (Cai et al. 2014). These are initial global results from a globally distributed forest gap model. Ma et al. (2017) mention several improvements that would be invaluable in the model and in the available data. Nonetheless, the agreement between the FORCCHN results and predictions from other global models using different assumptions are robust convergence of outcomes.

\section{Conclusions}

In this paper, we have focused on individual-based gap models of forests across the time and space domains of their applications. These models draw strongly from information on the silvics, allometry and environmental responses of individual tree species. These descriptive parameters are usually estimated from descriptions of the tree species and not fitted to data. For example, a parameter for tree maximum height for a species might have some variability in its estimate, but it could not be estimated to be $500 \mathrm{~m}$, even if this produced better statistical fits to a data set. Other significant parts of the models include, for example, standard biophysical models for evapotranspiration of biogeochemical models for nutrients released by decomposition. Here again, the parameters are not assigned arbitrary values for best statistical fit. What these features mean is that these models are more likely to be tested for agreement with data, rather than fit to data.

A new generation of satellite observation systems have the capability to provide new observations to test existing model predictions. This class of models can efficiently interact in a hypothesis-testing mode in at least three ways: 


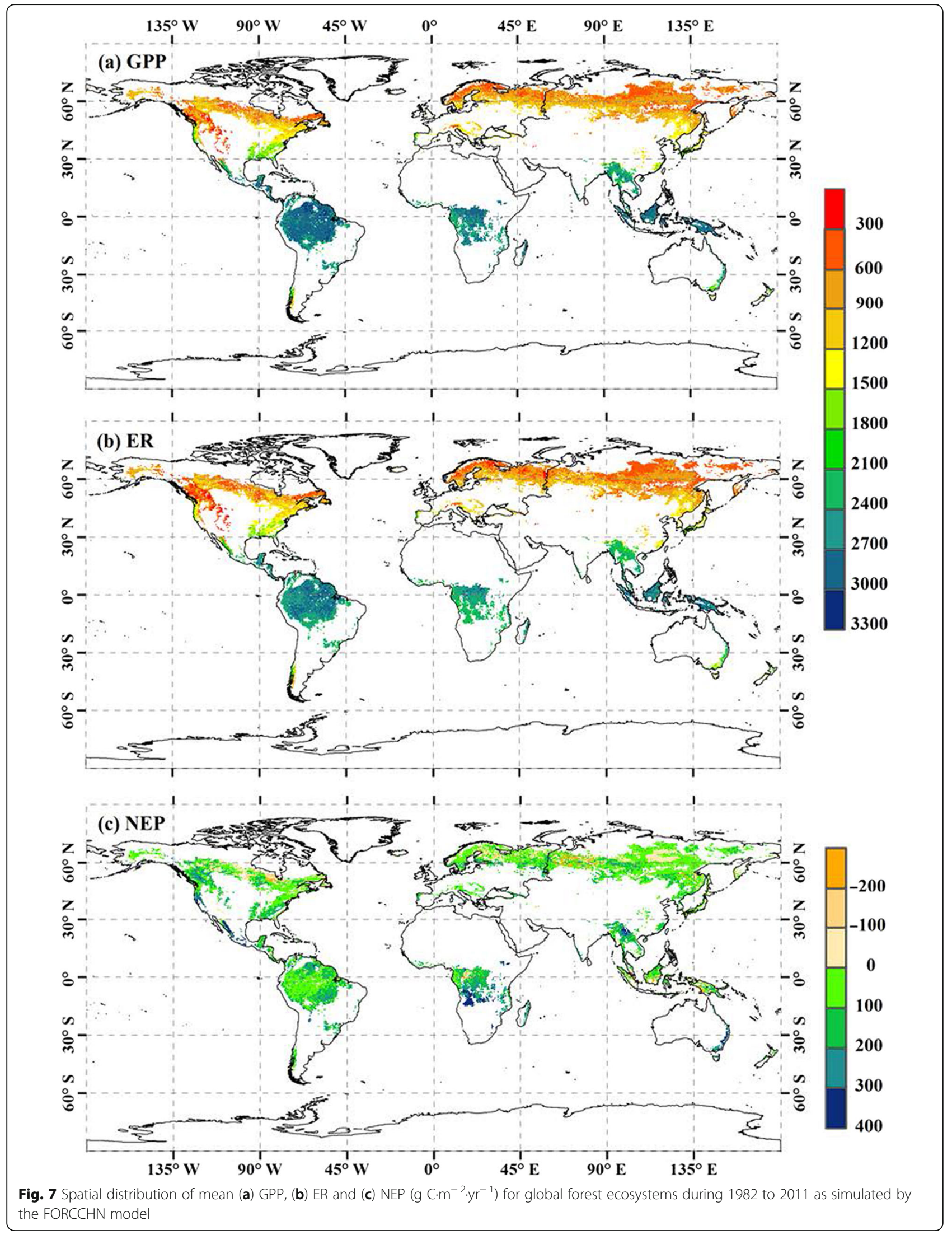


1) One can use the models for predicting the expected patterns of variability among important ecological variables as simulated by the models. These predictions include a priori estimation of expected composition of forests (Asner et al. 2012), remote sensing observations implying physical structure of forests and their relationships to biomass (Köhler and Huth 2010; Le Toan et al. 2011; Saatchi et al. 2011; Lobo and Dalling 2014), productivity (Yang et al. 2015) and VOCs (Fu et al. 2019).

2) One can use remote sensing and gap models to predict how ecosystem processes produce patterns across scales from micro to global. While previous field studies typically needed to specify a spatial scale of interest prior to sampling forests, the finescale and global coverage of remote sensing products, along with the available computing power for model simulations, enables the simulation of finescale processes across large spatial extents, encompassing all of the intermediate scales along that spectrum. While ecologists have long been interested in the relevance of scale on ecological processes, these approaches now provide a clear means to explicitly evaluate the impact of scale on patterns, such as suggested by hierarchy theory (O’Neill 1989).

3) Our microscale example shows how ecological processes may also affect multiple scales. While the canopy positions of tree species at a gap scale affects the competitive growth rates of individual trees, it also contributes to the regional production of ozone at larger scales, which in turn impacts fine-scale competitive interactions by favoring ozone-resistant species. Such scale-spanning interactions are also inherent in studies involving forests and climate change as we discuss in our global example. While the uptake of carbon dioxide through photosynthesis is ultimately dependent on leaf-level physiology, the global scale consequences of that uptake influence climate depending on whether forests serve as a carbon source or sink. The global summation of that physiological process returns to affect the competitive interactions between tree species at fine scales, as species' competitive ability will change along with a changing climate. Remote sensing and model data will be needed to test predictions on how these processes impact forest ecosystems across scales.

\section{Acknowledgements}

Megan McGroddy read and commented on earlier versions of the paper. This manuscript given in the 2019 Autumn Workshop at the Beijing Forestry University and we are grateful for the comments of our fellow presenters and the conference participants.

\section{Authors' contributions}

Each author contributed different sections of the paper according to their expertise and they shared the effort to produce this paper equally. The authors read and approved the final manuscript.

\section{Funding}

Shugart was funded by the USA NASA grant NNH16ZDA001N-ESUSPI; Saatchi by USA NASA grant WBS: 509496.02.08.09.66; Foster by USA NASA ABoVE grant NNX17AE44G and USA DoD SERDP grant RC18-1183; Yang by USA NASA grant (IDS -- 80NSSC17K0110), and USA NSF grant (AGS-1837891); Lerdau by USA NSF-ATMO 1837891; Druckenbrod by USA NSF Hydrologic Sciences grant 1561473.

Availability of data and materials

Non-Archived.

Ethics approval and consent to participate

Not applicable.

Consent for publication

Not applicable.

\section{Competing interests}

The authors declare that they have no competing interests.

\section{Author details}

'University of Virginia, 291 McCormick Rd, Charlottesville, VA 22904, USA. ${ }^{2}$ NASA Goddard Space Flight Center, 8800 Greenbelt Rd, Greenbelt, MD 20771, USA. ${ }^{3}$ Department of Ecology and Evolutionary Biology, University of California, Irvine, CA, USA. ${ }^{4}$ Department of Geological, Environmental, and Marine Sciences, Rider University, 2083 Lawrenceville Rd, Lawrenceville, NJ 08648, USA. ${ }^{5}$ College of Plant Science and Technology, Huazhong Agriculture University, Wuhan, Hubei, China. ${ }^{6}$ Jet Propulsion Laboratory, California Institute of Technology, Pasadena, CA 91109, USA. ${ }^{7}$ Beijing Normal University, Jingshi Keji Building B-811, NO.12 Xueyuan South Road, Haidian District, Beijing 100875, China.

Received: 31 October 2019 Accepted: 2 March 2020

Published online: 23 March 2020

\section{References}

Anten NP, Hirose T (2001) Limitations of photosynthesis of competing individuals in stands and the consequences for canopy structure. Oecologia 129: 186-196

Araujo MB, Luoto M (2007) The importance of biotic interactions for modelling species distributions under climate change. Glob Ecol Biogeogr 16:743-753

Asner GP, Knapp DE, Boardman J, Green RO, Kennedy-Bowdoin T, Eastwood M, Martin RE, Anderson C, Field CB (2012) Carnegie airborne Observatory-2: increasing science data dimensionality via high-fidelity multi-sensor fusion. Remote Sens Environ 124:454-465

Beer C, Reichstein M, Tomelleri E, Ciais P, Jung M, Carvalhais N, Rodenbeck C, Arain MA, Baldocchi D, Bonan GB, Bondeau A, Cescatti A, Lasslop G, Lindroth A, Lomas M, Luyssaert S, Margolis H, Oleson KW, Roupsard O, Veenendaal E, Viovy N, Williams C, Woodward Fl, Papale D (2010) Terrestrial gross carbon dioxide uptake: global distribution and covariation with climate. Science 329:834-838

Berg EE, Henry JD, Fastie CL, De Volder AD, Matsuoka SM (2006) Spruce beetle outbreaks on the Kenai peninsula, Alaska, and Kluane National Park and Reseve, Yukon territory: relationship to summer temperatures and regional differences in disturbance regimes. Forest Ecol Manag 227:219-232

Bonan G (1989) A computer model of the solar radiation, soil moisture, and soil thermal regimes in boreal forests. Ecol Model 45:275-306

Bonan GB, Pollard D, Thompson SL (1992) Effects of boreal forest vegetation on global climate. Nature 359:275-306

Botkin DB, Janak JF, Wallis JR (1972) Some ecological consequences of a computer model of forest growth. J Ecol 60:849

Brazhnik K, Hanley C, Shugart HH (2017) Simulating changes in fires and ecology of the 21st century Eurasian boreal forests of Siberia. Forests 8:49. https://doi.org/10.3390/f8020049 
Brazhnik K, Shugart HH (2015) 3-D simulation of boreal forests: structure and dynamics in complex terrain and in a changing climate. Environ Res Lett 10:105006. https://doi.org/10.1088/1748-9326/10/10/105006

Brazhnik K, Shugart HH (2016) SIBBORK: a new spatially-explicit gap model for boreal forest. Ecol Model 320:182-196

Bugmann H (2001) A comparative analysis of forest dynamics in the Swiss Alps and the Colorado front range. Forest Ecol Manag 145:43-55

Bugmann HKM, Solomon AM (2000) Explaining forest composition and biomass across multiple biogeographical regions. Ecol Appl 10:95-114

Burns RM, Honkala BH (1990) Silvics of North America: 1. Conifers; 2. Hardwoods, vol 2. Agricultural handbook 654. U.S. Department of Agriculture. Forest Service, Washington, DC., p 877

Cai W, Yuan W, Liang S, Liu S, Dong W, Chen Y, Liu D, Zhang H (2014) Large differences in terrestrial vegetation production derived from satellite-based light use efficiency models. Remote Sens 6:8945-8965

Chapin FS III, Hollingsworth T, Murray DF, Viereck LA, Walker MD (2006a) Floristic diversity and vegetation distribution in the Alaskan boreal forest. In: Chapin FS III, Oswood MW (eds) Alaska's changing boreal forest. Oxford University Press, Oxford, pp 81-99

Chapin FS III, Viereck LA, Adams P, Van Cleve K, Fastie CL, Ott RA, Mann D, Johnstone JF (2006b) Successional processes in the Alaskan boreal forest. In: Chapin F, Oswood M (eds) Alaska's changing boreal forest. Oxford University Press, New York, pp 100-120

Coppo P, Taiti A, Pettinato L, Francois M, Taccola M, Drusch M (2017) Fluorescence imaging spectrometer (FLORIS) for ESA FLEX mission. Remote Sens 9(7):649

Delcourt HR, Delcourt PA, Webb T III (1983) Dynamic plant ecology: the spectrum of vegetation change in space and time. Quaternary Sci Rev 1:153-175

Derderian DP, Dang H, Aplet GH, Binkley D (2016) Bark beetle effects on a sevencentury chronosequence of Engelmann spruce and subalpine fir in Colorado, USA. Forest Ecol Manag 361:154-162

DeRose RJ, Long JN (2012) Factors influencing the spatial and temporal dynamics of Engelmann spruce mortality during a spruce beetle outbreak on the Markagunt plateau, Utah. For Sci 58:1-14

Druckenbrod DL, Martin-Benito D, Orwig DA, Pederson N, Poulter B, Renwick KM, Shugart $\mathrm{HH}$ (2019) Redefining temperate forest responses to climate and disturbance in the eastern United States: new insights at the mesoscale. Glob Ecol Biogeogr 28:557-575

Eswar R, Das NN, Poulsen C, Behrangi A, Swigart J, Svoboda M, Entekhabi D, Yueh S, Doorn B, Entin J (2018) SMAP soil moisture change as an indicator of drought conditions. Remote Sens 10(5):788

Euskirchen ES, McGuire AD, Chapin FS III, Yi S, Thompson CC (2009) Changes in vegetation in northern Alaska under scenarios of climate change, 2003-2100: implications for climate feedbacks. Ecol Appl 19:1022-1043

Fan L, Wigneron J-P, Ciais P, Chave J, Brandt M, Fensholt R, Saatchi SS, Bastos A, Al-Yaari A, Hufkens K, Qin Y, Xiao X, Chen C, Myneni RB, Fernandez-Moran R, Mialon A, Rodriguez-Fernandez NJ, Kerr Y, Tian F, Peñuelas J (2019) Satelliteobserved pantropical carbon dynamics. Nat Plants 5:944-951

Fischer R, Bohn F, de Paula MD, Dislich C, Groenveld J, Gutiérrez AG, Kazmierczak M, Knapp N, Lehmann S, Paulick S, Putz S, Rodig E, Taubert F, Kohler P, Huth A (2016) Lessons learned from applying a forest gap model to understand ecosystem and carbon dynamics of complex tropical forests. Ecol Model 326:124-133

Fisher JB, Hayes DJ, Schwalm CR, Huntzinger DN, Stofferahn E, Schaefer K, Luo Y, Wullschleger SD, Goetz S, Miller CE, Griffith P, Chadburn S, Chatterjee A, Ciais $P$, Douglas TA, Genet $H$, Ito A, Neigh CSR, Poulter B, Rogers BM, Sonnentag O, Tian H, Wang W, Xue Y, Yang Z, Zeng N, Zhang Z (2018) Missing pieces to modeling the Arctic-boreal puzzle. Environ Res Lett 13:020202

Fisher JB, Sikka M, Oechel WC, Huntzinger DN, Melton JR, Koven CD, Ahlström A, Arain MA, Baker I, Chen JM, Ciais P, Davidson C, Dietze M, El-Masri B, Hayes D, Huntingford C, Jain AK, Levy PE, Lomas MR, Poulter B, Price D, Sahoo AK, Schaefer K, Tian H, Tomelleri E, Verbeeck H, Viovy N, Wania R, Zeng N, Miller CE (2014) Carbon cycle uncertainty in the Alaskan Arctic. Biogeosciences 11:4271-4288

Flanagan PW, Van Cleve K (1983) Nutrient cycling in relation to decomposition and organic-matter quality in taiga ecosystems. Can J For Res 13:795-817

Foley JA (1994) Net primary productivity in the terrestrial biosphere: the application of a global model. J Geophys Res-Atmos 99(D10):20773-20783

Foster AC, Armstrong AH, Shuman JK, Shugart HH, Rogers BM, Mack MC, Goetz SJ, Ranson KJ (2019) Importance of tree- and species-level interactions with wildfire, climate, and soils in interior Alaska: implications for forest change under a warming climate. Ecol Model 409. https://doi.org/10.1016/j. ecolmodel.2019.108765
Foster AC, Shugart HH, Shuman JK (2015) Model-based evidence for cyclic phenomena in a high-elevation, two-species forest. Ecosystems 19:437-449

Foster AC, Shuman JK, Shugart HH, Dwire KA, Fornwalt PJ, Sibold J, Negron J (2017) Validation and application of a forest gap model to the southern Rocky Mountains. Ecol Model 351:109-128

Foster AC, Shuman JK, Shugart HH, Negron J (2018) Modeling the interactive effects of spruce beetle infestation and climate on subalpine vegetation. Ecosphere 9:e02437

Frankenberg C, Fisher JB, Worden J, Badgley G, Saatchi SS, Lee J-E, Toon GC, Butz A, Jung M, Kuze A, Yokota T (2011) New global observations of the terrestrial carbon cycle from GOSAT: patterns of plant fluorescence with gross primary productivity. Geophys Res Lett 38(17). https://doi.org/10.1029/2011GL048738

Friend AD, Shugart HH, Running SW (1993) A physiology-based gap model of forest dynamics. Ecology 74:792-797

Friend AD, Stevens AK, Knox RG, Cannel MGR (1997) A process-based, terrestrial biosphere model of ecosystem dynamics (hybrid v3.0). Ecol Model 95:249-287

Fu D, Millet DB, Wells KC, Payne VH, Yu S, Guenther A, Eldering A (2019) Direct retrieval of isoprene from satellite-based infrared measurements. Nat Commun 10:3811

Genet H, McGuire AD, Barrett K, Breen A, Euskirchen ES, Johnstone JF, Kasischke ES, Melvin AM, Bennett A, Mack MC, Rupp TS, Schuur AEG, Turetsky MR, Yuan $F$ (2013) Modeling the effects of fire severity and climate warming on active layer thickness and soil carbon storage of black spruce forests across the landscape in interior Alaska. Environ Res Lett 8:4

Global Soil Data Task Group (2000) Global gridded surfaces of selected soil characteristics (IGBP-DIS) dataset. Oak Ridge National Laboratory distributed active archive center, Oak Ridge, Tennessee http://daac.ornl.gov/. Accessed 15 Sept 2019

Greene DF, Johnson EA (1999) Modelling recruitment of Populus tremuloides, Pinus banksiana, and Picea mariana following fire in the mixedwood boreal forest. Can J For Res 29:462-473

Guenther A, Hewitt CN, Erickson D, Fall R, Geron C, Graedel T, Harley P, Klinger L, Lerdau M, McKay WA, Pierce T, Scholes B, Steinbrecher R, Tallamraju R, Taylor J, Zimmerman P (1995) A global model of natural volatile organic compound emissions. J Geophys Res-Atmos 100:8873-8892

Guenther AB, Jiang X, Heald CL, Sakulyanontvittaya T, Duhl T, Emmons LK, Wang $X$ (2012) The model of emissions of gases and aerosols from nature version 2.1 (MEGAN2.1): an extended and updated framework for modeling biogenic emissions. Geosci Model Dev 5:1471-1492

Hall FG, Bergen K, Blair JB, Dubayah R, Houghton R, Hurtt G, Kellndorfer J, Lefsky M, Ranson J, Saatchi S, Shugart HH, Wickland D (2011) Characterizing 3D vegetation structure from space: mission requirements. Remote Sens Environ 115:2753-2775

Hansen EM, Bentz BJ, Powell JA, Gray DR, Vandygriff JC (2011) Prepupal diapause and instar IV developmental rates of the spruce beetle, Dendroctonus rufipennis (Coleoptera: Curculionidae, Scolytinae). J Insect Physiol 57:1347-1357

Hansen WD, Chapin FS III, Naughton HT, Rupp S, Verbyl, D (2016) Forestlandscape structure mediates effects of a spruce bark beetle (Dendroctonus rufipennis) outbreak on subsequent likelihood of burning in Alaskan boreal forest. For Ecol Manag 369:38-46

Harley PC, Monson RK, Lerdau MT (1999) Ecological and evolutionary aspects of isoprene emission from plants. Oecologia 118:109-123

Hart SJ, Veblen TT, Kulakowski D (2014) Do tree and stand-level attributes determine susceptibility of spruce-fir forests to spruce beetle outbreak in the early 21st century? Forest Ecol Manag 318:44-53

Hart SJ, Veblen TT, Mietkiewicz N, Kulakowski D (2015) Negative feedbacks on bark beetle outbreaks: widespread and severe spruce beetle infestation restricts subsequent infestation. PLoS One 10(5):e0127975

Hood SM, Varner JM, van Mantgem P, Cansler CA (2018) Fire and tree death: understanding and improving modeling of fire-induced tree mortality. Environ Res Lett 13:113004

Huston M, DeAngelis DL, Post WM (1988) New computer models unify ecological theory. BioScience 38:682-691

Huston M, Smith T (1987) Plant succession: life history and competition. Am Nat 130:168-198

Huth A, Ditzer T (2000) Simulation of the growth of a lowland Dipterocarp rain forest with FORMIX 3 . Ecol Model 134:1-25

IPCC (2014) Summary for policymakers. In: Field CB, Barros VR (eds) Climate change 2014: impacts, adaptation, and vulnerability. Part a: global and sectoral aspects. Contribution of working group II to the fifth assessment report of the intergovernmental panel on climate change. Cambridge University Press, Cambridge and New York, p 1132 
Jenkins MJ, Hebertson EG, Munson AS (2014) Spruce beetle biology, ecology, and management in the Rocky Mountains: an addendum to spruce beetles in the Rockies. Forests 5:21-71

Johnstone JF, Chapin FS III, Hollingsworth TN, Mack MC, Romanovsky V, Turetsky M (2010a) Fire, climate change, and forest resilience in interior Alaska. Can J For Res 40:1302-1312

Johnstone JF, Hollingsworth TN, Chapin FS III, Mack MC (2010b) Changes in fire regime break the legacy lock on successional trajectories in Alaskan boreal forest. Glob Chang Biol 16:1281-1295

Johnstone JF, Rupp TS, Olson M, Verbyla D (2011) Modeling impacts of fire severity on successional trajectories and future fire behavior in Alaskan boreal forests. Landsc Ecol 26:487-500

Joiner J, Yoshida Y, Vasilkov AP, Schaefer K, Jung M, Guanter L, Zhang Y, Garrity S, Middleton EM, Huemmrich KF, Gu L, Belelli Marchesini L (2014) The seasonal cycle of satellite chlorophyll fluorescence observations and its relationship to vegetation phenology and ecosystem atmosphere carbon exchange. Remote Sens Environ 152:375-391

Jung M, Reichstein M, Margolis HA, Cescatti A, Richardson AD, Arain MA, Arneth A, Bernhofer C, Bonal D, Chen J, Gianelle D, Gobron N, Kiely G, Kutsch W, Lasslop G, Law BE, Lindroth A, Merbold L, Montagnani L, Moors EJ, Papale D, Sottocornola M, Vaccari F, Williams C (2011) Global patterns of landatmosphere fluxes of carbon dioxide, latent heat, and sensible heat derived from eddy covariance, satellite, and meteorological observations. J Geophys Res-Biogeo 116:G00J07

Justice CO, Kendall JD, Dowty PR, Scholes RJ (1996) Satellite remote sensing of fires during the SAFARI campaign using NOAA advanced very high resolution radiometer. J Geophys Res-Atmos 101:23851-23863. https://doi.org/10.1029/95JD00623

Keane RE, Austin M, Field C, Huth A, Lexer MJ, Peters D, Solomon A, Wyckoff P (2001) Tree mortality in gap models: application to climate change. Clim Chang 51:509-540

King AW, Post WM, Wullschleger SD (1997) The potential response of terrestrial carbon storage to changes of climate and atmospheric $\mathrm{CO}_{2}$. Clim Chang 35 : 199-227

Kirschbaum MUF, Paul KI (2002) Modelling C and N dynamics in forest soils with a modified version of the CENTURY model. Soil Biol Biochem 34:341-354

Köhler P, Huth A (2010) Towards ground-truthing of spaceborne estimates of above-ground life biomass and leaf area index in tropical rain forests. Biogeosciences 7:2531-2543

Krinner G, Viovy N, de Noblet-Ducoudré N, Ogée J, Polcher J, Friedlingstein P, Ciais P, Sitch S, Prentice IC (2005) A dynamic global vegetation model for studies of the coupled atmosphere-biosphere system. Global Biogeochem Cy 19:GB1015

Larocque GR, Archambault L, Delisle C (2006) Modelling forest succession in two southeastern Canadian mixedwood ecosystem types using the ZELIG model. Ecol Model 199:350-362

Larocque GR, Archambault L, Delisle C (2011) Development of the gap model ZELIG-CFS to predict the dynamics of north American mixed forest types with complex structures. Ecol Model 222:2570-2583

Larocque GR, Shugart HH, Xi W, Holm JA (2016) Forest succession models. In: Larocque GR (ed) Ecological forest management handbook. CRC Press, Taylor and Frances Group, London, pp 233-266

Le Toan T, Quegan S, Davidson MWJ, Balzter H, Paillou P, Papathanassiou K, Plummer S, Rocca F, Saatchi S, Shugart H, Ulander L (2011) The BIOMASS mission: mapping global forest biomass to better understand the terrestrial carbon cycle. Remote Sens Environ 115:2850-2860

Lefsky MA, Cohen WB, Parker GG, Harding DJ (2002) Lidar remote sensing for ecosystem studies: Lidar, an emerging remote sensing technology that directly measures the three-dimensional distribution of plant canopies, can accurately estimate vegetation structural attributes and should be of particular interest to forest, landscape, and global ecologists. BioScience 52:19-30

Lerdau MT (2007) A positive feedback with negative consequences. Science 316:212-213

Lerdau MT, Slobodkin L (2002) Trace gas emissions and species-dependent ecosystem services. Trends Ecol Evol 17:309-312

Lertzman K, Fall J (1998) From forest stands to landscapes: spatial scales and the roles of disturbances. In: Peterson DL, Parker VT (eds) Ecological scale: theory and applications. Columbia University Press, New York, pp 339-367

Liang S, Zhao X, Liu S, Yuan W, Cheng X, Xiao Z, Zhang X, Liu Q, Cheng J, Tang H, Qu Y, Bo Y, Qu Y, Ren H, Yu K, Townshend J (2013) A long-term global
LAnd surface satellite (GLASS) data-set for environmental studies. Int J Digit Earth 6:5-33

Liu Z, Notaro M, Kutzbach J, Liu N (2006) Assessing global vegetation-climate feedbacks from observations. J Clim 19:787-814

Lobo E, Dalling JW (2014) Spatial scale and sampling resolution affect measures of gap disturbance in a lowland tropical forest: implications for understanding forest regeneration and carbon storage. Proc R Soc B 281:1-8

Loreto F, Fineschi S (2014) Reconciling functions and evolution of isoprene emission in higher plants. New Phytol 206:578-582

Loveland T, Brown J, Ohlen D, Reed B, Zhu Z, Yang L, Howard S (2009) ISLSCP ॥ IGBP DISCover and SiB land cover, 1992-1993. Oak Ridge National Laboratory distributed active archive center, Oak Ridge, Tennessee http://daac.ornl.gov/. Accessed 15 Sept 2019

Ma J, Shugart HH, Yan X, Cao C, Wu S, Fang J (2017) Evaluating carbon fluxes of global forest ecosystems by using an individual tree-based model FORCCHN. Sci Total Environ 586:939-951. https://doi.org/10.1016/j.scitotenv.2017.02.073

McDowell NG, Allen CD (2015) Darcy's law predicts widespread forest mortality under climate warming. Nat Clim Chang 5:669-672

McGuire AD, Melillo JM, Joyce LA, Kicklighter DW, Grace AL, Moore B, Vorosmarty CJ (1992) Interactions between carbon and nitrogen dynamics in estimating net primary productivity for potential vegetation in North America. Global Biogeochem Cy 6:101-124

Mekonnen ZA, Riley WJ, Randerson JT, Grant RF, Rogers BM (2019) Expansion of high-latitude deciduous forests driven by interactions between climate warming and fire. Nat Plants 5:952-958

Monson RK, Jones RT, Rosenstiel TN, Schnitzler J-P (2013) Why only some plants emit isoprene. Plant Cell Environ 36:503-516

Monteith JL (1981) Evaporation and the environment. In: Fogg CE (ed) The state and movement of water in living organisms. Cambridge University Press, Cambridge, pp 205-234

Nachtergaele F, Van Velthuyzen H, Verelst L, Wiberg D (2012) Manual harmonized world soil database (v1.2). FAO, Rome

Nemani RR, Keeling CD, Hashimoto H, Jolly WM, Piper SC, Tucker CJ, Myneni RB, Running SW (2003) Climate-driven increases in global terrestrial net primary production from 1982 to 1999. Science 300:1560-1563. https://doi.org/10. 1126/science. 1082750

O'Connor CD, Lynch AM, Falk DA, Swetnam TW (2015) Post-fire forest dynamics and climate variability affect spatial and temporal properties of spruce beetle outbreaks on a Sky Island mountain range. Forest Ecol Manag 336:148-162

O'Neill RV, Johnson AR, King AW (1989) A hierarchical framework for the analysis of scale. Landsc Ecol 3:193-205.

Parton WJ, Scurlock JMO, Ojima DS, Gilmanov TG, Scholes RJ, Schimel DS, Kirchner T, Menaut J-C, Seastedt T, Moya EG, Kamnalrut A, Kinyamario JI (1993) Observations and modeling of biomass and soil organic matter dynamics for the grassland biome worldwide. Global Biogeochem Cy 7:785-809

Pastor J, Post WM (1985) Development of a linked forest productivity-soil process model. Environmental Sciences Division Publication, USDOE, Oak Ridge National Laboratory

Peng C, Liu J, Dang Q, Apps MJ, Jiang H (2002) TRIPLEX: a generic hybrid model for predicting forest growth and carbon and nitrogen dynamics. Ecol Model 153:109-130

Penman HL (1948) Natural evaporation from open water, bare soil and grass. P Roy Soc Lond A 193:120-145

Potter CS, Randerson JT, Field CB, Matson PA, Vitousek PM, Mooney HA, Klooster SA (1993) Terrestrial ecosystem production: a process model based on global satellite and surface data. Global Biogeochem Cy 7:811-841

Prentice IC, Cramer W, Harrison SP, Leemans R, Monserud RA, Solomon AM (1992) A global biome model based on plant physiology and dominance, soil properties and climate. J Biogeogr 19:117-134.

Purves D, Pacala S (2008) Predictive models of forest dynamics. Science 320: 1452-1453

Raffa KF, Aukema BH, Bentz BJ, Carroll AL, Hicke JA, Turner MG, Romme WH (2008) Cross-scale drivers of natural disturbances prone to anthropogenic amplification: the dynamics of bark beetle eruptions. BioScience 58:501-517

Saatchi S, Asefi-Najafabady S, Malhi Y, Aragão LE, Anderson LO, Myneni RB, Nemani R (2013) Persistent effects of a severe drought on Amazonian forest canopy. PNAS 110(2):565-570

Saatchi SS, Harris NL, Brown S, Lefsky M, Mitchard ETA, Salas W, Zutta BR, Buermann W, Lewis SL, Hagen S, Petrova S, White L, Silman M, Morel A (2011) Benchmark map of forest carbon stocks in tropical regions across three continents. PNAS 108:9899-9904 
Schumacher S, Reineking B, Sibold J, Bugmann H (2006) Modeling the impact of climate and vegetation on fire regimes in mountain landscapes. Landsc Ecol 21:539-554

Seidl R, Thom D, Kautz M, Martin-Benito D, Peltoniemi M, Vacchiano G, Wild J, Ascoli D, Petr M, Honkaniemi J, Lexer MJ, Trotsiuk V, Mairota P, Svoboda M, Fabrika M, Nagel TA, Reyer CPO (2017) Forest disturbances under climate change. Nat Clim Chang 7:395-402

Sellers PJ, Mintz Y, Sud YC, Dalcher A (1986) A simple biosphere model (SiB) for use within general circulation models. J Atmos Sci 43:505-531

Sellers PJ, Randall DA, Collatz GJ, Berry JA, Field CB, Dazlich DA, Zhang C, Collelo GD, Bounoua L (1996) A revised land surface parameterization (SiB2) for atmospheric GCMs. Part I: Model formulation J Climate 9:676-705

Sheffield J, Goteti G, Wood EF (2006) Development of a 50-year high-resolution global dataset of meteorological forcings for land surface modeling. J Clim 19:3088-3111

Shugart HH (1984) A theory of forest dynamics: the ecological implications of forest succession models. Springer-Verlag, New York, p 278

Shugart HH (1998) Terrestrial ecosystems in changing environments. Cambridge University Press, Cambridge, p 537

Shugart HH, Asner GP, Fischer R, Huth A, Knapp N, Le Toan T, Shuman JK (2015) Computer and remote-sensing infrastructure to enhance large-scale testing of individual-based forest models. Front Ecol Environ 13:503-511. https://doi.org/10.1890/140327

Shugart HH, Saatchi S, Hall FG (2010) Importance of structure and its measurement in quantifying function of forest ecosystems. J Geophys ResBiogeo 115, G00E13, https://doi.org/10.1029/2009JG000993

Shugart HH, Seagle SW (1985) Modeling forest landscapes and the role of disturbance in ecosystems and communities. In: Pickett STA, White PS (eds) The ecology of natural disturbance and patch dynamics. Academic Press, San Diego, pp 353-368

Shugart HH, Smith TM, Post WM (1992) The potential for application of individual-based simulation models for assessing the effects of global change. Ann Rev Ecol Syst 23:15-38

Shugart HH, Wang B, Fischer R, Ma J, Fang J, Yan X, Huth A, Armstrong AH (2018) Gap models and their individual-based relatives in the assessment of the consequences of global change. Environ Res Lett 13:033011. https://doi.org/ 10.1088/1748-9326/aaaacc

Shugart HH, West DC (1977) Development of an Appalachian deciduous forest succession model and its application to assessment of the impact of the chestnut blight. J Environ Manag 5:161-179

Shugart HH, Woodward FI (2011) Global change and the terrestrial biosphere: achievements and challenges. Wiley-Blackwell, Oxford, p 242

Shuman JK, Foster AC, Shugart HH, Hoffman-Hall A, Krylov A, Loboda T, Ershov D, Sochilova E (2017) Fire disturbance and climate change: implications for Russian forests. Environ Res Lett 12:035003. https://doi.org/10.1088/17489326/aa5eed

Shuman JK, Tchebakova N, Parfenova E, Soja A, Shugart HH, Ershov D, Holcomb K (2015) Forest forecasting with vegetation models across Russia. Can J For Res 45:175-184

Sitch S, Cox PM, Collins WJ, Huntingford C (2007) Indirect radiative forcing of climate change through ozone effects on the land-carbon sink. Nature 448:791-794

Sitch S, Smith B, Prentice IC, Arneth A, Bondeau A, Cramer W, Kaplan JO, Levis S, Lucht W, Sykes MT, Thonicke K, Venevsky S (2003) Evaluation of ecosystem dynamics, plant geography and terrestrial carbon cycling in the LPJ dynamic global vegetation model. Glob Chang Biol 9:161-185

Smith B, Prentice IC, Sykes MT (2008) Representation of vegetation dynamics in the modelling of terrestrial ecosystems: comparing two contrasting approaches within European climate space. Glob Ecol Biogeogr 10:621-637

Smith TM, Urban DL (1988) Scale and the resolution of forest structural pattern. Vegetatio 74:143-150

Solomon AM (1986) Comparison of taxon calibrations, modern analog techniques, and forest-stand simulation models for the quantitative reconstruction of past vegetation: a critique. Earth Surf Proc Land 11:681-685

Solomon AM, Delcourt HR, West DC, Blasing TJ (1980) Testing a simulation model for reconstruction of prehistoric forest-stand dynamics. Quat Res 14: 275-293

Solomon AM, West DC, Solomon JA (1981) Simulating the role of climate change and species immigration in forest succession. In: West DC, Shugart HH (eds) Forest succession: concepts and application. Springer-Verlag, New York, pp 154-177

Song C, Woodcock CE (2003) A regional forest ecosystem carbon budget model: impacts of forest age structure and land use history. Ecol Model 164:33-47
Sykes MT, Prentice IC (1996) Climate change, tree species distributions and forest dynamics - a case study in the mixed conifer northern hardwoods zone of northern Europe. Clim Chang 34:161-177

Tansley AG (1935) The use and abuse of vegetational concepts and terms. Ecology 16:284-307

Trugman AT, Fenton NJ, Bergeron Y, Xu X, Welp L, Medvigy D (2016) Climate, soil organic layer, and nitrogen jointly drive forest development after fire in the north American boreal zone. J Adv Model Earth Sy 8:1180-1209

Tucker CJ (1979) Red and photographic infrared linear combinations for monitoring vegetation. Remote Sens Environ 8:127-150

Tucker CJ, Pinzon JE, Brown ME, Slayback DA, Pak EW, Mahoney R, Vermote EF, Saleous NE (2005) An extended AVHRR 8-km NDVI dataset compatible with MODIS and SPOT vegetation NDVI data. Int J Remote Sens 26:4485-4498

Urban DL, Bonan GB, Smith TM, Shugart HH (1991) Spatial applications of gap models. Forest Ecol Manag 42:95-110

van Tongeren O, Prentice IC (1986) A spatial simulation model for vegetation dynamics. Vegetatio 65:163-173

Vance ED, Chapin FS III (2001) Substrate limitations to microbial activity in taiga forest floors. Soil Biol Biochem 33:173-188

Veblen TT, Hadley KS, Nel EM, Kitzberger T, Reid M, Villalba R (1994) Disturbance regime and disturbance interactions in a rocky mountain subalpine forest. J Ecol 82:125-135

Veblen TT, Hadley KS, Reid MS, Rebertus AJ (1991) The response of subalpine forests to spruce beetle outbreak in Colorado. Ecology 72:213-231

Viereck LA, Dyrness CT, Van Cleve K, Foote MJ (1983) Vegetation, soils, and forest productivity in selected forest types in interior Alaska. Can J For Res 13:703-720

Wang B, Shugart HH, Lerdau MT (2017a) An individual-based model of forest volatile organic compound emissions-UVAFME-VOC v1. 0. Ecol Model 350:69-78

Wang B, Shugart HH, Lerdau MT (2017b) Sensitivity of global greenhouse gas budgets to tropospheric ozone pollution mediated by the biosphere. Environ Res Lett 12:084001

Wang B, Shugart HH, Lerdau MT (2019) Complexities between plants and the atmosphere. Nat Geosci 12:693-694. https://doi.org/10.1038/s41561-019-0413-8

Wang B, Shugart HH, Shuman JK, Lerdau MT (2016) Forests and ozone: productivity, carbon storage, and feedbacks. Sci Rep 6:22133

Wang B, Shuman J, Shugart HH, Lerdau MT (2018) Biodiversity matters in feedbacks between climate change and air quality: a study using an individual-based model. Ecol Appl 28:1223-1231

Weishampel JF, Urban DL, Shugart HH, Smith JB (1992) Semivariograms from a forest transect gap model compared with remotely sensed data. J Veg Sci 3:521-526

Wiens JA (1989) Spatial scaling in ecology. Funct Ecol 3:385-397

Woodward FI (1987) Climate and plant distribution. Cambridge University Press, Cambridge

Yan X, Shugart HH (2005) FAREAST: a forest gap model to simulate dynamics and patterns of eastern Eurasian forests. J Biogeogr 32:1641-1658

Yang X, Tang J, Mustard JF, Lee J-E, Rossini M, Joiner J, Munger JW, Kornfeld A, Richardson AD (2015) Solar-induced chlorophyll fluorescence that correlates with canopy photosynthesis on diurnal and seasonal scales in a temperate deciduous forest. Geophys Res Lett 42(8):2977-2987

Zhang Q, Alfaro Rl, Hebda RJ (1999) Dendroecological studies of tree growth, climate and spruce beetle outbreaks in Central British Columbia, Canada. Forest Ecol Manag 121:215-225

Zhou L, Tian Y, Myneni RB, Ciais P, Saatchi S, Liu YY, Piao S, Chen H, Vermote EF, Song C, Hwang $T$ (2014) Widespread decline of Congo rainforest greenness in the past decade. Nature 509:86-90 